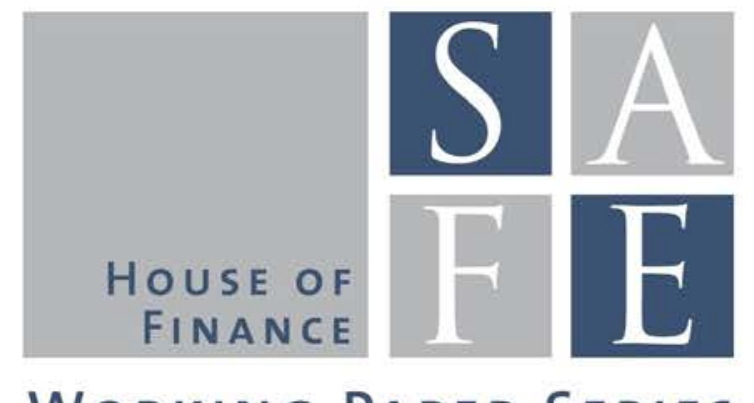

Working PAPER SERIES

Nathanael Vellekoop

\title{
Explaining Intra-Monthly Consumption Patterns: The Timing of Income or the Timing of Consumption Commitments?
}

SAFE Working Paper No. 237

SAFE I Sustainable Architecture for Finance in Europe A cooperation of the Center for Financial Studies and Goethe University Frankfurt 


\title{
Explaining Intra-Monthly Consumption Patterns: The Timing of Income or the Timing of Consumption Commitments?
}

\author{
Nathanael Vellekoop ${ }^{\dagger}$ \\ Goethe University Frankfurt \& SAFE
}

November $2018^{*}$

\begin{abstract}
A number of recent studies have concluded that consumer spending patterns over the month are closely linked to the timing of income receipt. This correlation is interpreted as evidence of hyperbolic discounting. I re-examine patterns of spending in the diary sample of the U.S. Consumer Expenditure Survey, incorporating information on the timing of the main consumption commitment for most households - their monthly rent or mortgage payment. I find that non-durable and food spending increase with $30-48 \%$ on the day housing payments are made, with smaller increases in the days after. Moreover, households with weekly, biweekly and monthly income streams but the same timing of rent/mortgage payments have very similar consumption patterns. Exploiting variation in income, I find that households with extra liquidity decrease non-durable spending around housing payments, especially those households with a large budget share of housing.
\end{abstract}

Keywords: consumption, consumption commitments, paycheck frequency, liquidity. JEL classification: D12, D14, E21

${ }^{*}$ I greatly appreciate David Card's hospitality and advice. Many thanks to Rob Alessie, Katie Carman, Raj Chetty, Meltem Daysal, Carlos Dobkin, Thomas Dohmen, Bill Evans, Patrick Hullegie, Tobias Klein, Peter Kooreman, Chris Müris, Jan Potters, Jesse Shapiro, Mel Stephens, Arthur van Soest, and Mirko Wiederholt for generous comments. Special thanks to Mel Stephens for sharing non-public CEX data. Laura Paszkiewicz of the Bureau of Labor Statistics was very helpful whenever I had questions about the CEX data. Thanks to seminar participants at UC Berkeley, UC Santa Barbara, Cal State East Bay, the San Francisco Fed, Frankfurt, Maastricht, Tilburg, and UC Santa Cruz for helpful comments. I gratefully acknowledge research support from the Research Center SAFE, funded by the State of Hessen initiative for research LOEWE. Thanks to the research department of the San Francisco Fed for their hospitality. All remaining errors are mine.

$\dagger$ vellekoop@safe.uni-frankfurt.de, Theodor-W.-Adorno-Platz 3, 60323 Frankfurt am Main, Germany, tel. +496979830075 . 


\section{Introduction}

A typical month for many households would be that the household receives income, pays the bills, and has at its disposal what remains. The "bills" consist of expenditures like mortgage or rent payments, health insurance and car loan payments. These expenditures are typically to be paid every month, the budget share is large, and adjustments are not frequently made (Chetty and Szeidl, 2007). Moreover, late or missing payments of these socalled consumption commitments can result in fees, fines, or eviction in the case of housing. In the case of housing payments, there is an additional issue: in the U.S. housing payments can typically only be made with cash, not with a credit card. This creates a situation where households have a precautionary demand for money, in order to have enough cash balances to pay for monthly consumption commitments (Telyukova, 2013). For many households, especially the ones that are liquidity constrained, the timing of housing payments and the timing of non-durable spending are both part of household money management. As such, an unexplored question is how non-durable spending responds to the timing of housing payments.

It is well studied how household consumption responds to income receipt (see e.g. Browning and Collado (2001); Stephens Jr. (2003); Shapiro (2005); Ni and Seol (2014). A key prediction of the permanent income hypothesis is that consumption should respond to the arrival of new information about income, but not to the timing of income changes (unless the consumer is liquidity constrained). Some more recent studies use the timing of wage and benefit payments to test this prediction, under the assumption that the schedule of wage payments or benefit income is known. Examples are Stephens Jr. (2003) and Mastrobuoni and Weinberg (2009) for Social Security recipients, Shapiro (2005) for food stamp recipients, and Gelman et al. (2014) for wage earners and Social Security recipients using data from a financial account aggregator. The common finding is that both consumption expenditures and food intake are sensitive to the timing of regular, predictable income payments, so-called "pay-day effects". Mastrobuoni and Weinberg (2009) and Gelman et al. (2014) show that these results are largest for households with low levels of liquid assets. However, over the course of a month, low liquidity by itself cannot explain the spike in consumption on the day of income receipt. Both Shapiro (2005); Mastrobuoni and Weinberg (2009) fit models of hyperbolic discounting and argue that models with self-control problems (in combination with liquidity constraints) can explain pay-day effects. Based on these results, one could advocate a potential welfare improvement in the spirit of "nudges" (Thaler and Sunstein, 2008): alter the frequency of paychecks, and instead of monthly payments, offer weekly or biweekly payments, holding total monthly amounts constant (Shapiro, 2005; Dobkin and Puller, 2007; Mastrobuoni and Weinberg, 2009; Parsons and Wesep, 2013).

The focus on the income side is only half of the story. In the short-run, fixed expenditures like housing payments are a given. Liquidity management by the household requires attention to both income receipt and timely payment of consumption commitments. Moreover, if households are liquidity-constrained, then housing payments have a higher priority to the household than non-durable spending. In other words, liquidity constrained house- 
holds do not loose much welfare by postponing non-durable spending until after the housing payment is made. I use daily diary data from the U.S. survey of consumer expenditures (CEX) to investigate how households change non-durable and food spending in the days before and after housing payments are made. In the first part of the analysis I show how households with weekly, biweekly and monthly paychecks increase non-durable spending around the day of housing payment. Specifically, non-durable household spending increases between 41.8-48.4\% on the day the household pays rent or mortgage, and in a similar fashion for all three paycheck frequencies. This implies that households with different income streams adjust non-durable spending until after the housing payment is made, in line with a precautionary demand for money motive. In the second part of the empirical analysis I exploit some quasi-experimental variation in household liquidity. Biweekly paid households have to time a paycheck every other week with a monthly housing payment. Ten housing payments have to be made on two checks, and two housing payments have three paychecks preceding. I find that biweekly paid households increase non-durable spending between 6.6-10.4\% in the fourteen days of such an "extra" paycheck. Moreover, biweekly paid households decrease their spending response around housing payments in episodes with an "extra" paycheck, especially households with a larger budget share of housing.

These findings matter for three reasons. First, the empirical finding that households adjust non-durable spending around the payment of the largest outflow of most households is new (to the best of my knowledge). Second, the documented consumption response to income receipt can by confounded by the timing of large fixed expenditures. What has been reported as excess sensitivity to income receipt, could be a delayed spending response in anticipation of the timing of housing payments. In the short-run both income flows and fixed expenditures matter for the budget constraint and available liquidity of the household. Finally, my findings suggest that the budget share of large, fixed expenditures could be a relevant source of consumer heterogeneity. If so, this might provide further insights in consumer responses to fiscal and monetary policy.

This study is related to two strands in the literature, the response of consumption to income receipt, and the literature on consumption commitments. The existence of a within monthly cycle in consumption expenditures and caloric intake is well studied. Stephens Jr. (2003) uses the CEX diary data for the years 1986 - 1996. He documents an increase in consumption expenditures in the first week after Social Security checks are distributed. This is a violation of the lifecycle hypothesis if consumption expenditures are correlated with actual consumption. Mastrobuoni and Weinberg (2009) show that caloric intake follows consumption expenditures. They use a food intake survey and find a monthly cycle for caloric intake around the payment of Social Security. This cycle is found for households with less than $\$ 5,000$ in savings, but not for households with higher levels of assets. For low-asset households exponential discounting is rejected in favor of hyperbolic discounting. Using experimental evidence, Carvalho, Meier and Wang (2016) find that economic preferences and risk attitudes are the same before and after income payments. Evans and Moore (2012) find a cycle around the first of the calendar month for Social Security recipients for the years 1996 - 2004. Not only for Social Security recipients, they also find a cycle around the first of the month for several other subgroups: households whose head has less 
than a college degree, recipients of federal assistance, and households with a family income less than $\$ 30,000$. In the same study they document an intra-monthly cycle in a rather different outcome variable than consumption. Based on administrative data they report that mortality increases in the first week of the month relative to the last week. This cycle in mortality only exists for causes of death that are related to activity such as homicides, heart attacks and traffic accidents. There is no cycle for cancer related causes of death. Evans and Moore argue that there is a causal chain from excess liquidity to activity, resulting in a higher probability of mortality. This is evidence that households do not respond to income per se, but to disposable liquidity. In the empirical section I estimate models with controls for the first of the month. A monthly cycle in household expenditures could trigger a response by firms. Hastings and Washington (2010) use scanner data from the U.S. and find that supermarkets have a pro-cyclical pricing strategy: prices are high at the beginning of the month and low at the end. Consumers would be better off to shift shopping to the end of the month. All mentioned studies only focus on the payment of income and the response of the household to income receipt. To the best of my knowledge, there are no studies that look into how well households smooth consumption with respect to housing payments.

The literature on consumption commitments acknowledges that it is costly to change the level of major consumption expenditures. Consumption commitments are defined as goods for which it is costly to change the level of consumption. Chetty and Szeidl (2007) show that consumption commitments affect risk preferences by amplifying risk attitudes towards moderate-stake risks, and that they create a motive to take large pay-off gambles. Following up in a second study, Chetty and Szeidl (2010) use consumption commitments as a foundation for a model with reference-dependent preferences and habit formation. Shore and Sinai (2010) present and test a model in which an increase in income risk in the presence of consumption commitments is associated with an increase in consumption, contrary to what a model with precautionary savings would predict. Finally Postlewaite, Samuelson and Silverman (2008) analyze a model in which consumption commitments can induce risk-neutral households to be risk averse over small variations in income, but sometimes to seek risk over large variations. They show that optimal employment contracts will smooth wages conditional on being employed, but may incorporate a possibility of unemployment. I investigate how the timing of housing payments-the prototypical consumption commitment-affects non-durable and food spending.

The structure of this paper is as follows. The next section reviews some predictions from consumer theory, followed by a description of the data and the empirical strategy. The first set of results documents the main finding, that non-durable spending increases on the day of housing payments. The second set of results exploits some quasi-experimental variation in household liquidity, and shows how household spending around housing payments changes in months with extra liquidity. The last section concludes. 


\section{Predictions from Theory}

A growing body of evidence finds that household consumption responds to income payments, and to a lesser extent to the arrival of news of income payments. This points to households having low levels of liquidity at any given point in time and/or the inability to borrow. For example, Baugh et al. (2018) report that consumption increases after tax returns are received (see also Souleles (1999)), but they find no response for households who need to pay taxes. Moreover, households receiving tax returns respond to the arrival of cash, and not to the moment they learn they will receive a tax return. Parker et al. (2013) show the same differential response between arrival of news and actual payments of the 2008 stimulus program. Misra and Surico (2014) uncover quite heterogeneous spending responses to the 2001 and 2008 tax rebates, where the households most likely to respond are renters and home-owners with a large mortgage debt (and thus likely to have a large budget share of housing payments). Gelman et al. (2014) find that non-recurring spending increases the day households receive their paycheck or Social Security check, and this response is larger for households with less liquid assets (Mastrobuoni and Weinberg (2009) find that actual food intake follows the same pattern for Social Security recipients with less than 5,000 in liquid assets). Kaplan and Violante (2014) rationalize consumption responses to tax rebates in a two-asset model, where households make a choice to invest in an illiquid asset with a larger return (e.g. a house) and liquid assets with a lower return. They argue that the group of households which is de facto liquidity constrained can be much larger-even middle income households owning a house can be liquidity constrained. Indeed, for several countries Kaplan, Violante and Weidner (2014) document a sizable class of "wealthy hand-to-mouth" consumers (in addition to the "classical" liquidity constrained who do not own real assets).

A point overlooked so far is that for hand-to-mouth consumers the structure and timing of fixed expenditures matters. Both poor and wealthy hand-to-mouth consumers need to pay rent or mortgage payments in the short run, over the course of a typical month. By definition hand-to-mouth consumers set their consumption expenditures equal to their income. The combination of a tight budget and large housing payments that have to be made by a certain date generates a preference ordering in spending. 11 Missing or postponing a housing payment is costly. The intuition is that when a hand-to-mouth household approaches the day of a housing payment, with each day of spending the budget becomes tighter. The cost of postponing some non-durable spending a few days until the housing payment is made is small, and could be smaller than the benefits of not hitting the liquidity constraint. A prediction from this insight is that in the short run the budget share of fixed expenditures could be a source of relevant heterogeneity in explaining consumption responses.

One way to rationalize why liquidity constrained households would postpone nondurable spending until housing payments are made is the following. Housing payments in the U.S. can typically not be made with a credit card, but need to be paid with cash

\footnotetext{
${ }^{1} \mathrm{I}$ thank Luigi Pistaferri for pointing this out.
} 
(Telyukova, 2013). This creates a cash-holding problem where households need to be sure to have enough liquidity of a certain form to pay for rent or mortgage. To the extent that housing payments are paid with check, there is the additional constraint for the household to hold enough liquidity in a bank account to avoid bouncing checks. Telyukova $(\overline{2013})$ calls this phenomenon the precautionary demand for money, and Telyukova and Visschers (2013) show its importance for accounting for business-cycle behavior of nominal variables. I find that households postpone non-durable and food spending to the day that the housing payment is made.

\section{Data and Empirical Strategy}

\subsection{Data}

In the first part of the paper I study how the timing of payment of the main consumption commitment of most households - rent and mortgage payments - affects the timing of other expenditures. The dataset used is the US Consumption Expenditure diary Survey (CEX diary). The CEX diary is a repeated cross-section of around 4500 consumer unit: ${ }^{2}$ per year. Every household keeps a diary of consumption expenditures for up to 14 days. The survey mainly asks for high-frequency consumption categories, for example food at home, food away, personal care and travel expenditures. Crucial for this paper is that households record the date of rent and mortgage payment ${ }^{3}$

The start of a diary is a random day in the year, with oversampling of households in December. Each wage-earner in the household is asked for the frequency of payment of the last paycheck. However, the exact date of payment is not recorded. Since 2012 the CEX does not included the date of purchase in the public use files anymore, and therefore I use the 26 waves spanning 1986-2011. The survey also collects information on household composition, labor earnings and other sources of income. One advantage of the CEX diary is that higher frequency consumption goods such as food spending are measured, to abstract from the problems of goods with a durables' dimension. Though consumption expenditures are measured well, there are notable issues like measurement error and top-coding in income variables and incomplete reporting. Response rates are around $80 \%$.

Households with 1 or 2 earners are included in the sample. Households that are flagged as incomplete income respondents are dropped, as are households with income from selfemployment and households who do not complete both diary weeks. Wage-earners are restricted to be one the three most common types of pay frequency in the United States: weekly, biweekly, and monthly. For households with two earners, the frequency of pay is determined by the earner whose annual wage income is at least $70 \%$ of the total household wage income, but results are robust to excluding two-earner households. There are 18,567

\footnotetext{
${ }^{2}$ I follow Stephens Jr. (2003) among others and use households and consumer units interchangeably.

${ }^{3}$ Housing payments are predominantly made at a monthly frequency. With a maximum of 14 diary days I will miss many housing payments because the housing payment falls outside the diary window. This is not a problem as long as the start date of the diary is random to the household, which is indeed the case
} 
households with 257, 684 observations, or around 13.8 days on average per household. This includes days with zero expenditures.

Table 1: Summary Statistics

\begin{tabular}{|c|c|c|c|c|}
\hline & All & Weekly Paid & Biweekly Paid & Monthly Paid \\
\hline Renter & 0.46 & 0.53 & 0.42 & 0.41 \\
\hline Owner with mortgage & 0.54 & 0.47 & 0.58 & 0.59 \\
\hline Average rent payment & 716 & 640 & 752 & 831 \\
\hline Average mortgage payment & 1,186 & 959 & 1,243 & 1,462 \\
\hline Budget share housing & 0.31 & 0.33 & 0.30 & 0.32 \\
\hline Age & 39.1 & 38.0 & 39.4 & 40.6 \\
\hline Male & 0.56 & 0.62 & 0.54 & 0.54 \\
\hline Low education (at most high-school) & 0.37 & 0.56 & 0.29 & 0.17 \\
\hline High education (college or more) & 0.32 & 0.14 & 0.37 & 0.62 \\
\hline Number of household members & 2.78 & 2.94 & 2.72 & 2.57 \\
\hline Two earner household & 0.32 & 0.30 & 0.34 & 0.28 \\
\hline Wage income household & 57,734 & 43,890 & 63,171 & 71,633 \\
\hline Household income after taxes & 48,492 & 37,136 & 53,150 & 58,686 \\
\hline Number of households & 18,567 & 6,014 & 10,781 & 1,772 \\
\hline
\end{tabular}

Table 1 presents the summary statistics of the households, for the overall sample and separately by frequency of paycheck. Around $46 \%$ of the households rent the home, and $54 \%$ owns the home with a mortgage. Weekly paid are more likely to rent a home, where biweekly paid and monthly paid have similar propensities. Conditional on renting or owning, there is a gradient in the size of the average rent or mortgage payment. However, the average budget share between the three groups is remarkably similar, around 0.31.4 As different as the three groups are in observable characteristics (e.g. education, income and household size $)^{5}$, the average budget share of housing is quite the same. Compared to others studies, the mean budgets share of rent/mortgage reported here is on the higher end.

\footnotetext{
${ }^{4}$ The budget share of mortgage and rent is calculated from the CEX diary data as the observed mortgage or rent payment, times twelve, divided by annual household income after taxes.

${ }^{5}$ One note on the relatively low fraction of two-earner households in the sample. This is a result of excluding two-earner households with different pay frequencies, where not one of the two earners could be assigned the main earner.
} 
using the CEX quarterly data Chetty and Szeidl (2007) report a budget share of 0.226 Other consumption commitments Chetty and Szeidl (2007) report (their Table 1, p. 835) are cars (excluding gas) with a budget share of 0.147, apparel (0.051), furniture/appliances (0.044), and health insurance (0.030). Housing expenditures have by far the largest budget share and are not frequently adjusted. I focus on households with rent and mortgage payments for three reasons. First, rent and mortgage payments generally have the largest budget share of all household expenditures. Second, they are to be paid every month and the consequences of missing a payment are potentially severe. Finally, the transaction costs of changing house are high. I take rent and mortgage payments as a proxy for total consumption commitments of the household! 7 .

About a third of the respondents in the data reports having made a mortgage or rent payment (around 18,500 households). This is not necessarily evidence for underreporting. The procedure for data collecting of the CEX diary data is such that households start their 14-day diary at any day of the month. It is likely that for many households the monthly rent or mortgage payment falls outside the diary window. This is not a threat to the analysis, as long as the first diary day is a random day during the year.

I follow Stephens Jr. (2003) in the construction of expenditure categories. Stephens distinguishes between food consumed at home, and food away from the home (expenditures on alcohol are included in both), and I add the two to create a measure of total food expenditures (Evans and Moore, 2012). The sum of food at home and food away allows for potential substitution patterns between the two over the course of the month. Since expenditures is not always the same as consumption, I follow Lusardi (1996); Stephens Jr. (2003) and construct a third category which is a measure of instant consumption. This category contains food away from home, alcohol away from home and entertainment expenditures. The fourth category (fresh food) aims to capture perishable goods, and includes eggs, milk products, fresh fruit, and fresh vegetables. The last measure (instant consumption) contains all strict nondurable goods, which is the sum of food at home, food away, personal products and services, public transport and gasoline and smoking supplies. All expenditures where the respondent indicates that it is a gift for somebody outside the household are dropped. Expenditures are deflated using the CPI of December 2010. Following previous studies (Stephens Jr., 2003) I drop households that have all expenditures recorded on the first day of the diary week. Reason is that when households record expenditures in a week, but without a date, the Bureau of Labor Statistics assigns all expenditures to the first day of a diary week.

\footnotetext{
${ }^{6}$ The CEX diary data and the CEX quarterly interview data are based on two independent samples.

${ }^{7} \mathrm{My}$ results are understating the true effect of consumption commitments if households lump the payment of several monthly payments together. Reasons to not include other recurring payments is that they are either not observed in the data (e.g. credit card payments), or there is a usage component to it (e.g. heating in the winter).
} 


\subsection{Housing Payments}

Most wage-earners in the United States receive their paycheck at a different frequency than monthly-biweekly paid (58\%) is the most common, followed by weekly paid (32\%). The frequency of rent and mortgage payments is not recorded in the CEX data, but is available in the Survey of Consumer Finances. Table 2 shows that almost all households pay their rent and mortgage once a month: $99.3 \%$ of the renters and $98.4 \%$ of the mortgage payers. That means that many households have to time a monthly outflow of large payments with a different frequency of wage income. Moreover, within the month, housing payments are made on any day of the calendar month. Many households in the CEX diary survey record the date when they pay their rent or mortgage. Figure 1 shows the distribution of rent and mortgage payments over the month in the sample. There is a mild U-shape visible - most of the payments are concentrated at the beginning and at the end of the calendar month. However, there is quite some variation in between, with for example small spikes on the 8th and the 15th of the month. The profile for the three paycheck frequencies is quite similar. Given that I only observe recorded rent/mortgage payments, I cannot assess whether payments are made on time, nor distinguish between early or late payments. Baugh et al. (2017) report the distribution of mortgage payments over the month for the recipients of Social Security in their sample. Their data comes from a financial account aggregator, so reporting issues are minimal. Moreover, they know the due date of mortgage payments- their graph $4 \mathrm{c}$ is very similar to Figure 1. In robustness checks I will investigate to what extent the results change for households who pay on the first of the month, a window of dates around the first of the month, and other days of the month. For now, I create an event-study and set the date of payment of rent or mortgage payment at $t=0$, and I center the days in weeks before and weeks after date of housing payment. Identification comes from the variation in payments of rent and mortgage within the month. A potential concern is that households can choose to postpone the day of rent or mortgage payments. This is however only a temporary solution for a household. Postponing a housing payment will make the time to next payment only shorter. Gelman et al. (2015) show that households have some discretion in changing the timing of payments, but this is in response to the negative income shock they study. They study the 2013 government shutdown, that induced an unexpected postponement of paychecks for government workers. They find that government workers affected postpone housing payments and payment of credit card balances, but there are no longer lasting effects after the shutdown was averted. 
Table 2: Frequency Distribution of Large, Recurring Payments

\begin{tabular}{lrrrr}
\hline & Rent & Mortgage & Car Loan & Education Loan \\
\hline Monthly & $99.3 \%$ & $98.4 \%$ & $99.1 \%$ & $98.5 \%$ \\
Other & $0.3 \%$ & $1.1 \%$ & $1.8 \%$ & $1.6 \%$
\end{tabular}

Fraction of households and payment frequency of selected categories. Source: Own calculations based on Survey of Consumer Finances, waves 1989, 1992, 1995, 1998, 2001, 2004, 2007 and 2010.
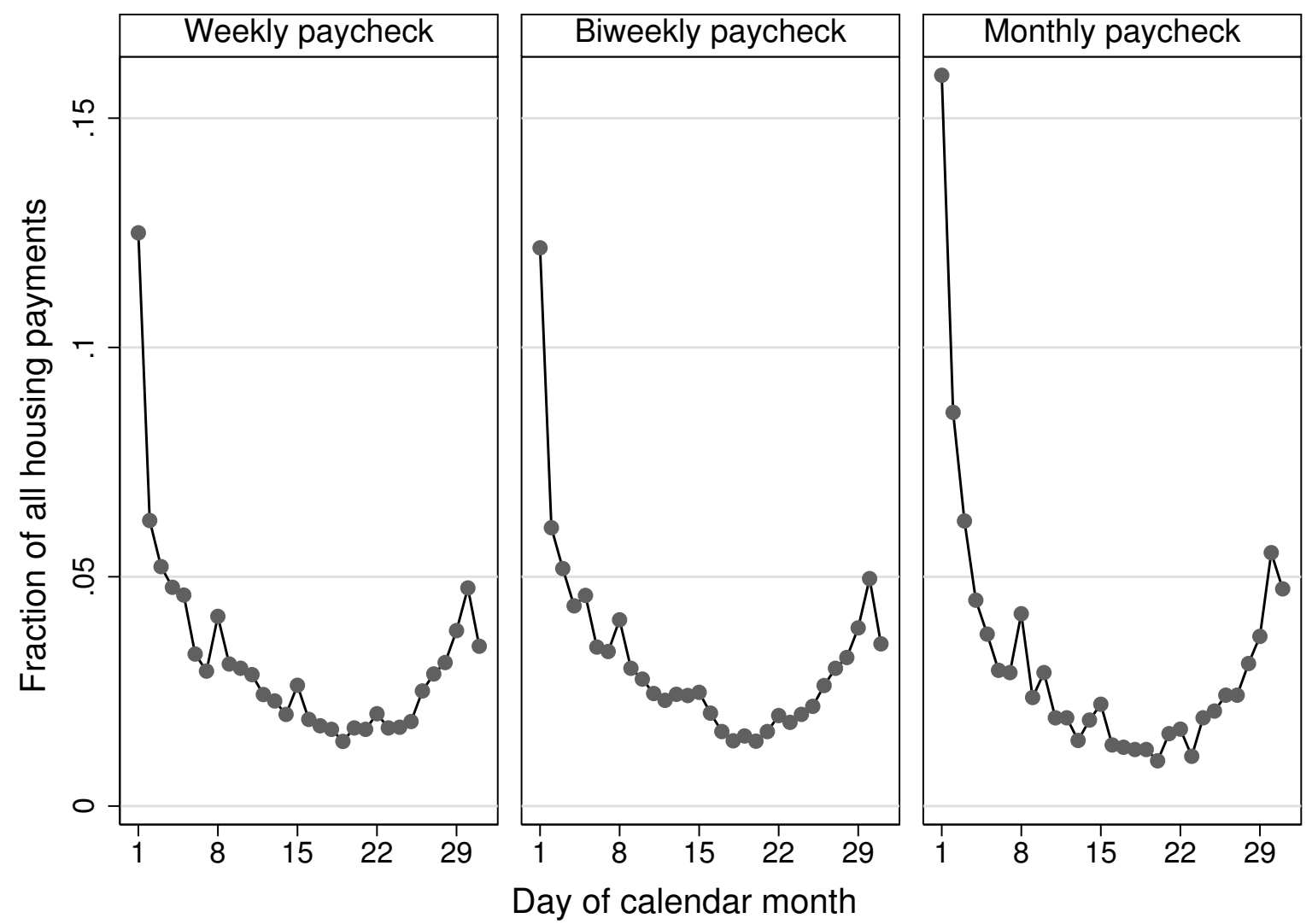

Figure 1: Frequency of Housing Payments over the Course of the Calendar Month 


\subsection{Empirical Model}

The baseline specification is:

$$
C_{i t}=\alpha_{i}+\beta_{1} d a y^{0}+\beta_{2} d a y^{1-3}+\beta_{3} d a y^{4-6}+\text { Calweek }_{j}+D O W_{k}+D O S_{l}+\epsilon_{i t} .
$$

$C_{i t}$ is the expenditures of household $i$ on day $t . C_{i t}$ can be one of the six consumption categories: strict nondurable consumption, total food, food at home, food away, instant expenditures, or fresh food. A household specific fixed effect $\alpha_{i}$ is included in the regression. Three dummies capture the effect of household expenditures around day of rent and mortgage payments. Variable $d a y^{0}$ is a dummy for the actual day of payment of rent or mortgage; day ${ }^{1-3}$ captures the first three days after and $d a y^{3-6}$ the next three days. This specification is based on the observation that many studies find the largest effect on the event-day, and some smaller effects in the days after, e.g (Gelman et al., 2014). Evans and Moore (2012) report a strong cycle in consumption expenditures around the first of the calendar month. To capture fixed effects of the calendar month I add dummies for the weeks of the calendar month. Two weeks before the first of the month is Calweek ${ }_{-2}$, the week before the first is the omitted category, the first week of the month is Calweek $k_{+1}$ and Calwee $_{+2}$ the second. Calwee $k_{+3}$ is not a full week, but contains 0 to 3 days, depending on the length of the month. I do not observe pay-dates of wages, but for monthly paid households these dummies might proxy for paycheck receipt as well. Variables $D O W_{k}$ and $D O S_{l}$ are dummies for the day of the week, respectively the day of the survey, to pick up effects of day of the week and effects of survey fatigue.

Consumption expenditures are zero on many days, and have a long right tail. I trim the top $2 \%$ of the dependent variable in each regression to account for extreme observations. Moreover, I transform the dependent variable with the inverse hyperbolic sine transformation (Burbidge, Magee and Robb, 1988), which is similar to the log in interpretation, but can account for values of zero. Equation (1) is estimated by OLS and I allow for arbitrary within household serial correlation by clustering standard errors at the level of the household.

\section{Empirical Results}

Figures $2 / 3$ show residuals averaged by event-time after taking out day of the week, day of the survey and day of the month effects, but not household fixed effects. The figures are separate regressions for weekly, biweekly, and monthly paid households. Time 0 is the day of the housing payment. Figure 2 shows that non-durable expenditures increase with about eight dollars on the day of the housing payment for weekly paid households, around seven dollars for biweekly, and about eight dollars for monthly paid households. For weekly paid households there are two smaller spikes to note, seven days before and seven days after the housing payment. If weekly paid households time their housing payment to the paycheck, the smaller spikes could be evidence for pay-day effects. However, the largest spending 
effect is on the day of the largest expenditure of the household. The figure for total food expenditures (Figure 3) show the same results. Food expenditures increase markedly on the day of the housing payment. The figures for the two underlying components of total food spending, food at home and food away can be found in the online appendix, and also the figures for instant consumption and fresh food (Figures A1 A4). For all three frequencies of paycheck, the same pattern is visible. Regardless of how frequent the household is paid, non-durable expenditures are strongly related to the timing of (monthly) housing payments.

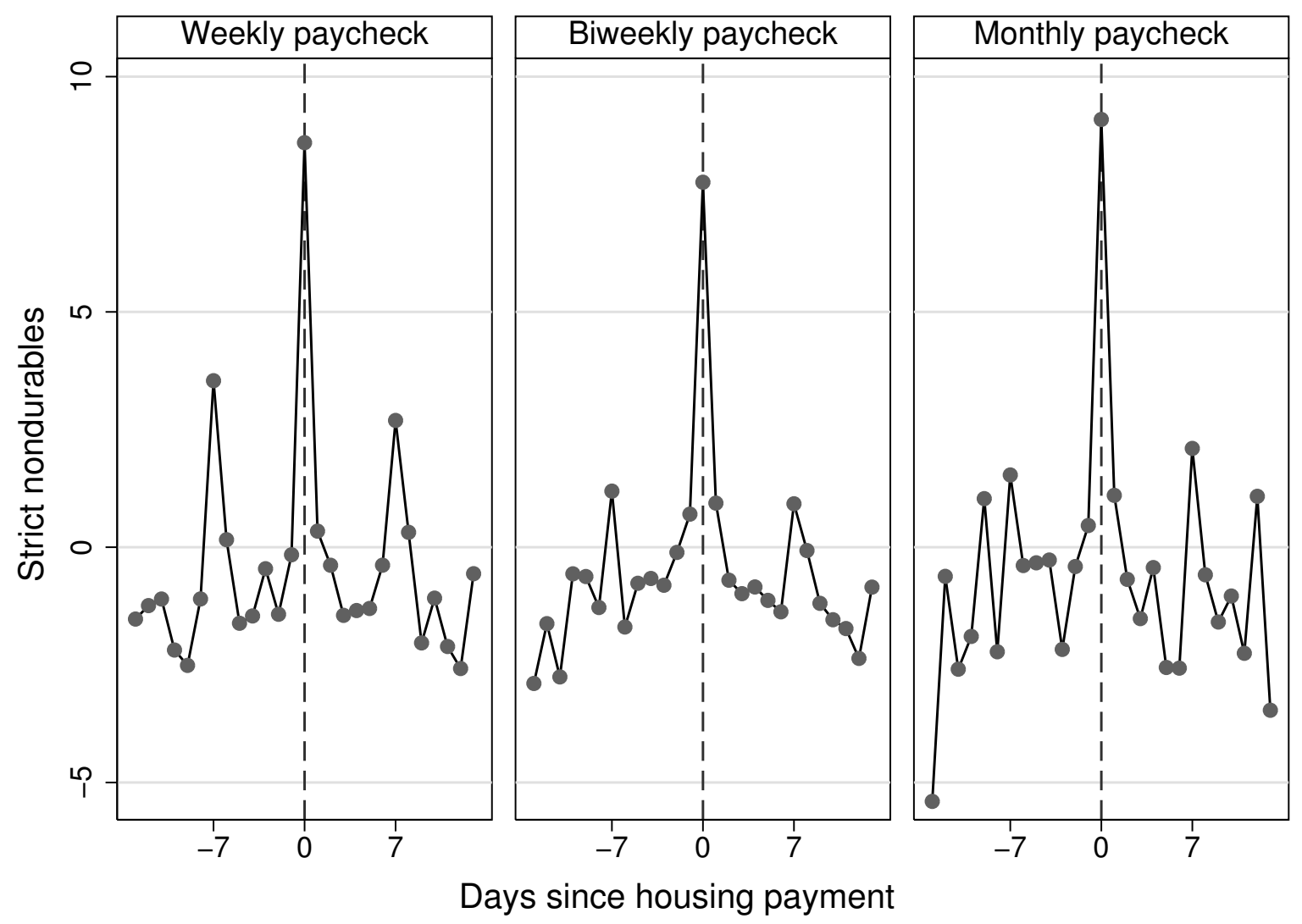

Figure 2: Daily Spending Around Housing Payment: Strict Nondurable Expenditures Averaged residuals constructed from three separate regressions controlling for day of the week, day of survey, and day of the calendar month.

\subsection{Regression Results}

Using the empirical model of equation 1 allows for inclusion of household fixed effects, as well as the analysis of the pattern of dynamics after housing payments. The main regression results are in Table 3 for strict non-durable spending (Panel A.) and total food consumption 


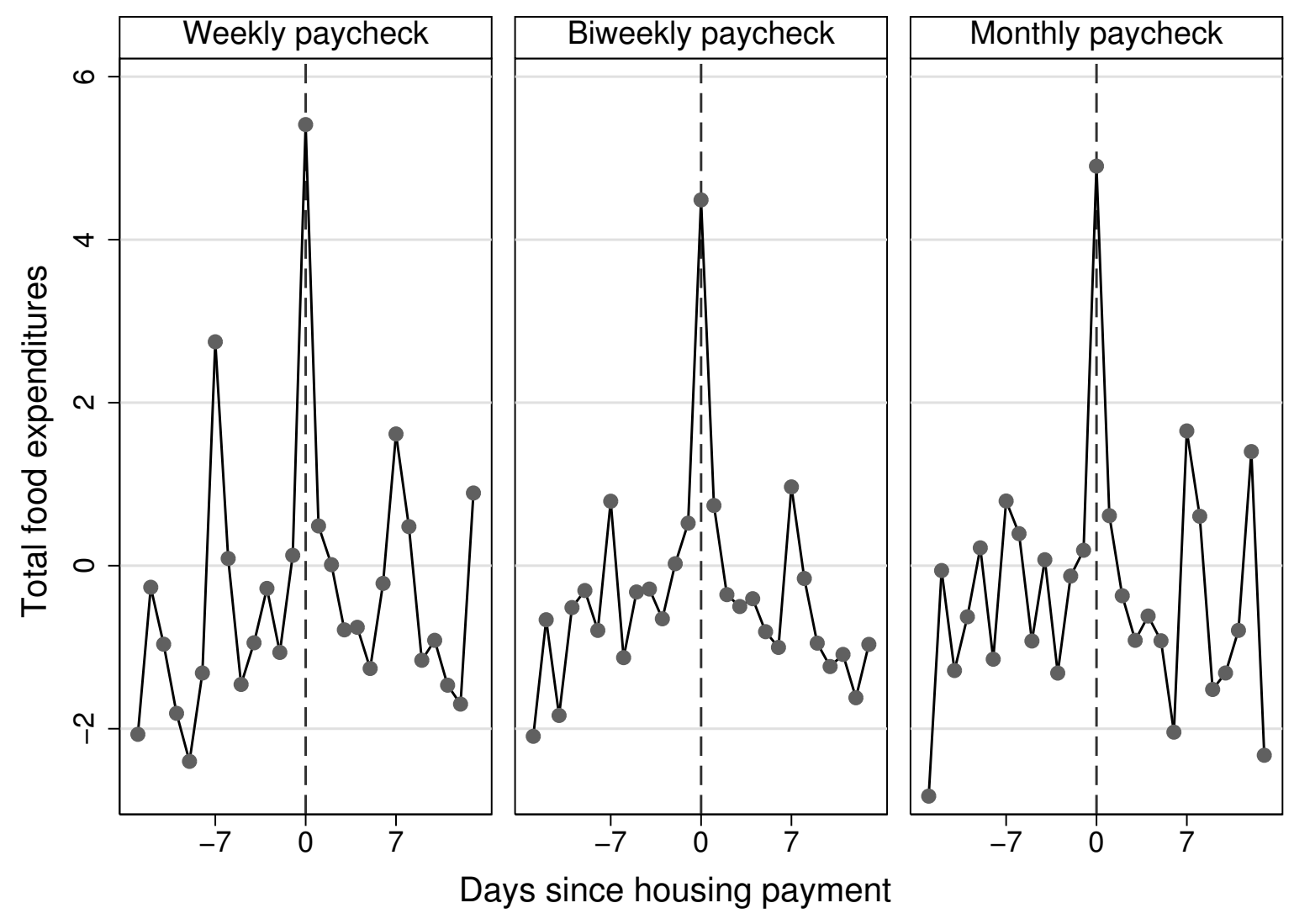

Figure 3: Daily Spending Around Housing Payment: Total Food Spending Averaged residuals constructed from three separate regressions controlling for day of the week, day of survey, and day of the calendar month. 
(Panel B.). Results for the other four consumption categories can be found in Tables A1 A2 in the online appendix. Each column is a separate regression, and the dependent variable is transformed using the inverse hyperbolic sine, which is similar in interpretation as the natural logarithm. There is a large, significant increase in non-durable spending and total food spending on the day that the rent or mortgage is paid. The size of the effect is similar across paychecks, approximately $48 \%$ for weekly paid households, $41 \%$ for biweekly, and $46 \%$ for monthly paid households. The effect-size is a little less than half a day's worth of spending on the day of the housing payment. The size is larger than what Stephens Jr. (2003) reports for the spending response to the arrival of Social Security income, and similar to what Gelman et al. (2014) report for the response of non-recurring spending to paycheck arrival. Considering the dynamics after the date of the housing payment, there is a small additional increase in spending in the three days after (although not significant for monthly paid households), and there is some mean reversion noticeable in the following days four to six (although not statistically significant for weekly paid households). Turning to the weeks of the calendar month in Table 3, there is no clear pattern around the first of the month visible after controlling for the days after the housing payment. Although Evans and Moore (2011) document a first of the month effect, they find strongest effects for recipients of welfare and Social Security.

Turning to panel B of Table 3, the same response is visible for total food expenditures. Again, relative effect sizes are quite similar for the three pay groups, even though there is a gradient in average daily food expenditures: 17.46 dollars for weekly paid to 19.09 dollars for monthly paid. In part this reflects the fact that biweekly paid earn higher wages than weekly paid, and monthly paid earn the highest wages on average. Despite the fact that the three pay groups are different in observable characteristics, and most likely on some unobservable characteristics as well (e.g. patience), the relative response of consumption expenditures to the timing of housing payments is quite similar. For total food spending there is again a small effect in the three days after four percent for weekly paid and three percent for biweekly paid, as well as some mean reversion in the 4-6 days after the housing payment is made.

Total food expenditures masks some different responses to food at home and food away from home-total food spending is the sum of the two. These responses are in Table A1. For food at home the responses are stronger for weekly paid households $(+41 \%)$ and smallest for monthly paid households $(+27.5 \%)$. For food away from home responses are smaller, but still relatively large ( $13 \%$ for monthly paid to $18 \%$ for weekly paid). Where food at home has some additional spending in the three days after the housing payment, these are small and not significant for food away from home (other than for biweekly paid). Table A2 shows the results for instant consumption and fresh food. Here the results range from $16 \%$ to $21 \%$ on the day of the housing payment. 
Table 3: Non-Durable and Total Food Expenditures After Housing Payments

\begin{tabular}{lcccccc}
\hline & \multicolumn{2}{c}{ A. Strict } & Nondurable Expenditures & \multicolumn{3}{c}{ B. Total Food Spending } \\
& $(1)$ & $(2)$ & $(3)$ & $(1)$ & $(2)$ & $(3)$ \\
& Weekly & Biweekly & Monthly & Weekly & Biweekly & Monthly \\
\hline Day of housing payment & $0.484^{* * *}$ & $0.418^{* * *}$ & $0.466^{* * *}$ & $0.395^{* * *}$ & $0.303^{* * *}$ & $0.314^{* * *}$ \\
& $(0.025)$ & $(0.019)$ & $(0.047)$ & $(0.024)$ & $(0.018)$ & $(0.046)$ \\
& $0.037^{* *}$ & $0.025^{*}$ & 0.024 & $0.042^{* *}$ & $0.031^{* *}$ & 0.010 \\
Housing payment: 1-3 days after & $(0.017)$ & $(0.013)$ & $(0.033)$ & $(0.017)$ & $(0.013)$ & $(0.032)$ \\
& -0.016 & $-0.026^{*}$ & $-0.091^{* *}$ & -0.018 & -0.016 & $-0.074^{* *}$ \\
& $(0.019)$ & $(0.015)$ & $(0.038)$ & $(0.019)$ & $(0.014)$ & $(0.036)$ \\
Housing payment: 4-6 days after & $0.068^{* * *}$ & $0.049^{* * *}$ & 0.046 & $0.054^{* * *}$ & $0.031^{* *}$ & 0.018 \\
& $(0.021)$ & $(0.016)$ & $(0.040)$ & $(0.020)$ & $(0.015)$ & $(0.039)$ \\
First of the month: 8-14 days before & -0.007 & 0.014 & 0.039 & -0.016 & 0.012 & 0.034 \\
& $(0.019)$ & $(0.014)$ & $(0.034)$ & $(0.019)$ & $(0.014)$ & $(0.034)$ \\
First of the month: 0-6 days after & $0.048^{* *}$ & $0.046^{* * *}$ & 0.052 & $0.039^{*}$ & $0.038^{* *}$ & 0.046 \\
& $(0.023)$ & $(0.017)$ & $(0.044)$ & $(0.022)$ & $(0.017)$ & $(0.043)$ \\
First of the month: 7-13 days after & $0.074^{* *}$ & -0.005 & $0.132^{* *}$ & $0.055^{*}$ & 0.005 & $0.128^{* *}$ \\
& $(0.031)$ & $(0.024)$ & $(0.063)$ & $(0.030)$ & $(0.023)$ & $(0.062)$ \\
First of the month: other days & yes & yes & yes & yes & yes & yes \\
& yes & yes & yes & yes & yes & yes \\
Day of the week & 25.36 & 26.39 & 26.97 & 17.46 & 18.41 & 19.09 \\
Day of the survey & 0.72 & 0.73 & 0.72 & 0.65 & 0.68 & 0.67 \\
Mean daily expenditures & 0.27 & 0.22 & 0.21 & 0.27 & 0.23 & 0.22 \\
Fraction nonzero expenditures & Adjusted R-squared & &
\end{tabular}

Each column is an OLS regression with household fixed effects. The dependent variable is transformed using the inverse hyperbolic sine, and trimmed at the 98 th percentile. The total number of observations (households) is 81,731 (6,018) for weekly paid households, 146,708 (10,784) for biweekly, and 24,093 $(1,772)$ for monthly. The dummy variable '1-3 days after housing payment' takes on value one for the first three days after a household pays rent or mortgage, and '4-6 days after housing payment' the three days following. All regressions contain controls for day of the week and day of the survey. The reference week for the weeks of the calendar month is the week before the first of the month. The dummy for 'First of the month: other days around' is not a full week, but contains in between 0 and 3 days, depending on the total number of days of the month. Robust standard errors (in parentheses) are clustered at the household level. ${ }^{* * *} / * * *$ correspond to $10 \% / 5 \% / 1 \%$ significance level.

\subsection{Observable Heterogeneity}

After documenting the increase in non-durable and food spending on the day of the housing payment, I explore the role of observable heterogeneity. First, I estimate regression model (1) for the three paycheck frequencies jointly, interacting the groups biweekly and monthly paid with dummies for the days around the housing payment. These results are reported in column 1 of Table 4 for non-durable spending and column 1 of Table 5 for total food spending. Results in column 1 summarize Table 3 in one specification (dummies for the week of the calendar month are included, but not reported). In columns (2) and (3) I split the sample by budget share of housing, the lowest quartile (column 2) and the highest quartile (column 3). Households with a high budget share of housing have a somewhat larger response (around $+50.3 \%$ ), but this is not too different from households with a low budget share (around $+47.1 \%$ ). There does not seem to be differential responses of biweekly paid or monthly paid on the day of the housing payment. The absolute response 
is larger in magnitude for households with a low budget share of housing, since average non-durable spending is about nine dollars higher for households with a small budget share of housing. In columns (4) and (5) the sample is split by renters and house-owners. Renters have a much stronger spending response than home-owners, which could indicate some liquidity constraints on the part of renters. Also the costs of missing or late payments could be much more severe for renter than for home-owners, though the data do not provide direct evidence on that. In the last two columns, the sample is split by household income. Households with incomes in the bottom quintile show a larger spending response $(+54.7 \%)$ than households in the top income quintile $(+41.8 \%)$. Both low and high income households can be de facto liquidity constrained. Kaplan and Violante (2014) report that even higher income households can be hand-to-mouth consumers, which is the consequence of binding themselves to illiquid assets, e.g. a house. Examining other spending categories show very much the same spending patterns as for durable spending. Total food spending in Table 5, and in the online appendix food at home (Table A3), food away (Table A4), instant consumption (Table A5), and fresh food (Table A6). Perhaps surprisingly, the results for the sample split on the budget share are not so clear, and sometimes different from what one would expect, e.g. the increase in food at home spending is larger for households with a low budget share of housing, and in general the differences in responses between the high and low budget share group are small. One possible explanation is that the sample split is noisy-housing payments are divided by disposable household income, and though only complete income reporters are included in the sample, income is quite noisy in the CEX data. 
Table 4: Heterogeneity: Non-Durable expenditures After Housing Payments

\begin{tabular}{|c|c|c|c|c|c|c|c|}
\hline & \multirow[b]{2}{*}{$\begin{array}{l}\text { Baseline } \\
(1)\end{array}$} & \multicolumn{2}{|c|}{ Budget Share Housing } & \multicolumn{2}{|c|}{ Housing Tenure } & \multicolumn{2}{|c|}{ Household Income } \\
\hline & & $\begin{array}{l}\text { Lowest } 25 \% \\
\text { (2) }\end{array}$ & $\begin{array}{l}\text { Highest } 25 \% \\
\text { (3) }\end{array}$ & $\begin{array}{l}\text { Rent } \\
(4)\end{array}$ & $\begin{array}{c}\text { Own Home } \\
(5)\end{array}$ & $\begin{array}{l}\text { Lowest } 20 \% \\
\text { (6) }\end{array}$ & $\begin{array}{c}\text { Highest } 20 \% \\
(7)\end{array}$ \\
\hline Day of housing payment & $\begin{array}{l}0.485^{* * *} \\
(0.025)\end{array}$ & $\begin{array}{l}0.471^{* * *} \\
(0.049)\end{array}$ & $\begin{array}{l}0.503^{* * *} \\
(0.046)\end{array}$ & $\begin{array}{l}0.515^{* * *} \\
(0.034)\end{array}$ & $\begin{array}{l}0.439^{* * *} \\
(0.036)\end{array}$ & $\begin{array}{l}0.547^{* * *} \\
(0.044)\end{array}$ & $\begin{array}{l}0.418^{* * *} \\
(0.077)\end{array}$ \\
\hline Housing payment: $1-3$ days after & $\begin{array}{c}0.029^{*} \\
(0.017)\end{array}$ & $\begin{array}{c}-0.021 \\
(0.034)\end{array}$ & $\begin{array}{l}0.061^{* *} \\
(0.031)\end{array}$ & $\begin{array}{l}0.059^{* * *} \\
(0.023)\end{array}$ & $\begin{array}{c}0.008 \\
(0.024)\end{array}$ & $\begin{array}{l}0.062^{* *} \\
(0.029)\end{array}$ & $\begin{array}{c}0.053 \\
(0.056)\end{array}$ \\
\hline Housing payment: $4-6$ days after & $\begin{array}{c}-0.025 \\
(0.018)\end{array}$ & $\begin{array}{c}-0.046 \\
(0.038)\end{array}$ & $\begin{array}{c}0.005 \\
(0.034)\end{array}$ & $\begin{array}{c}-0.011 \\
(0.025)\end{array}$ & $\begin{array}{c}-0.029 \\
(0.028)\end{array}$ & $\begin{array}{l}0.026 \\
(0.033)\end{array}$ & $\begin{array}{c}-0.048 \\
(0.064)\end{array}$ \\
\hline Biweekly pay $\times$ Day of housing payment & $\begin{array}{c}-0.066^{* *} \\
(0.031)\end{array}$ & $\begin{array}{c}-0.040 \\
(0.061)\end{array}$ & $\begin{array}{c}-0.088 \\
(0.061)\end{array}$ & $\begin{array}{c}-0.009 \\
(0.044)\end{array}$ & $\begin{array}{r}-0.084^{*} \\
(0.043)\end{array}$ & $\begin{array}{c}-0.038 \\
(0.062)\end{array}$ & $\begin{array}{c}-0.130 \\
(0.087)\end{array}$ \\
\hline Biweekly pay $\times 1-3$ days after housing payment & $\begin{array}{c}-0.003 \\
(0.021)\end{array}$ & $\begin{array}{c}0.061 \\
(0.042)\end{array}$ & $\begin{array}{c}-0.040 \\
(0.040)\end{array}$ & $\begin{array}{c}-0.008 \\
(0.029)\end{array}$ & $\begin{array}{c}0.006 \\
(0.029)\end{array}$ & $\begin{array}{c}-0.034 \\
(0.041)\end{array}$ & $\begin{array}{r}-0.040 \\
(0.062)\end{array}$ \\
\hline Biweekly pay $\times 4-6$ days after housing payment & $\begin{array}{r}-0.0001 \\
(0.023)\end{array}$ & $\begin{array}{c}0.058 \\
(0.046)\end{array}$ & $\begin{array}{r}-0.074^{*} \\
(0.043)\end{array}$ & $\begin{array}{c}-0.011 \\
(0.032)\end{array}$ & $\begin{array}{l}0.009 \\
(0.033)\end{array}$ & $\begin{array}{r}-0.075^{*} \\
(0.044)\end{array}$ & $\begin{array}{l}0.024 \\
(0.070)\end{array}$ \\
\hline Monthly pay $\times$ Day of housing payment & $\begin{array}{c}-0.012 \\
(0.052)\end{array}$ & $\begin{array}{c}-0.065 \\
(0.107)\end{array}$ & $\begin{array}{c}-0.009 \\
(0.101)\end{array}$ & $\begin{array}{c}-0.021 \\
(0.077)\end{array}$ & $\begin{array}{c}-0.005 \\
(0.071)\end{array}$ & $\begin{array}{c}-0.004 \\
(0.119)\end{array}$ & $\begin{array}{c}-0.107 \\
(0.119)\end{array}$ \\
\hline Monthly pay $\times 1-3$ days after housing payment & $\begin{array}{l}0.014 \\
(0.035)\end{array}$ & $\begin{array}{l}0.146^{* *} \\
(0.072)\end{array}$ & $\begin{array}{c}-0.030 \\
(0.071)\end{array}$ & $\begin{array}{c}0.043 \\
(0.053)\end{array}$ & $\begin{array}{c}-0.013 \\
(0.047)\end{array}$ & $\begin{array}{c}-0.009 \\
(0.076)\end{array}$ & $\begin{array}{c}-0.041 \\
(0.082)\end{array}$ \\
\hline Monthly pay $\times 4-6$ days after housing payment & $\begin{array}{r}-0.035 \\
(0.040)\end{array}$ & $\begin{array}{c}0.077 \\
(0.085)\end{array}$ & $\begin{array}{c}-0.062 \\
(0.074)\end{array}$ & $\begin{array}{c}0.021 \\
(0.057)\end{array}$ & $\begin{array}{c}-0.081 \\
(0.055)\end{array}$ & $\begin{array}{c}-0.030 \\
(0.089)\end{array}$ & $\begin{array}{c}-0.054 \\
(0.095)\end{array}$ \\
\hline Day of the week & yes & yes & yes & yes & yes & yes & yes \\
\hline Day of the survey & yes & yes & yes & yes & yes & yes & yes \\
\hline Week of the calendar month & yes & yes & yes & yes & yes & yes & yes \\
\hline Number of observations & 252,531 & 62,824 & 63,222 & 115,502 & 137,029 & 54,762 & 44,748 \\
\hline Number of households & 18,574 & 4,608 & 4,662 & 8,496 & 10,078 & 4,033 & 3,312 \\
\hline Mean daily expenditures & 26.11 & 30.52 & 21.74 & 20.84 & 30.68 & 16.47 & 39.78 \\
\hline Fraction nonzero expenditures & 0.73 & 0.76 & 0.68 & 0.69 & 0.76 & 0.64 & 0.80 \\
\hline Adjusted R-squared & 0.24 & 0.22 & 0.24 & 0.26 & 0.20 & 0.25 & 0.19 \\
\hline
\end{tabular}

Each column is an OLS regression with household fixed effects. The dependent variable is transformed using the inverse hyperbolic sine, and trimmed at the 98 th percentile. The dummy variable ' $1-3$ days after housing payment' takes on value one for the first three days after a household pays rent or mortgage, and '4-6 days after housing payment' the three days following. All regressions contain controls for day of the week, day of the survey, and week of the month. Household income is total household income before taxes. Robust standard errors (in parentheses) are clustered at the household level. $* / * * / * * *$ correspond to $10 \% / 5 \% / 1 \%$ significance level. 
Table 5: Heterogeneity: Total Food Expenditures After Housing Payments

\begin{tabular}{|c|c|c|c|c|c|c|c|}
\hline & \multirow[b]{2}{*}{$\begin{array}{l}\text { Baseline } \\
(1)\end{array}$} & \multicolumn{2}{|c|}{ Budget Share Housing } & \multicolumn{2}{|c|}{ Housing Tenure } & \multicolumn{2}{|c|}{ Household Income } \\
\hline & & $\begin{array}{l}\text { Lowest } 25 \% \\
\quad(2)\end{array}$ & $\begin{array}{c}\text { Highest } 25 \% \\
\text { (3) }\end{array}$ & $\begin{array}{c}\text { Rent } \\
(4)\end{array}$ & $\begin{array}{c}\text { Own Home } \\
(5)\end{array}$ & $\begin{array}{l}\text { Lowest } 20 \% \\
\quad(6)\end{array}$ & $\begin{array}{l}\text { Highest } 20 \% \\
\text { (7) }\end{array}$ \\
\hline Day of housing payment & $\begin{array}{l}0.395^{* * *} \\
(0.024)\end{array}$ & $\begin{array}{l}0.420^{* * *} \\
(0.049)\end{array}$ & $\begin{array}{l}0.424^{* * *} \\
(0.046)\end{array}$ & $\begin{array}{l}0.433^{* * *} \\
(0.033)\end{array}$ & $\begin{array}{l}0.342^{* * *} \\
(0.035)\end{array}$ & $\begin{array}{l}0.473^{* * *} \\
(0.043)\end{array}$ & $\begin{array}{l}0.323^{* * *} \\
(0.079)\end{array}$ \\
\hline Housing payment: $1-3$ days after & $\begin{array}{r}0.031^{*} \\
(0.016)\end{array}$ & $\begin{array}{c}-0.019 \\
(0.033)\end{array}$ & $\begin{array}{l}0.061^{* *} \\
(0.030)\end{array}$ & $\begin{array}{l}0.060^{* * *} \\
(0.022)\end{array}$ & $\begin{array}{c}0.009 \\
(0.023)\end{array}$ & $\begin{array}{l}0.060^{* *} \\
(0.028)\end{array}$ & $\begin{array}{l}0.020 \\
(0.056)\end{array}$ \\
\hline Housing payment: $4-6$ days after & $\begin{array}{c}-0.027 \\
(0.018)\end{array}$ & $\begin{array}{c}-0.046 \\
(0.037)\end{array}$ & $\begin{array}{c}0.006 \\
(0.033)\end{array}$ & $\begin{array}{c}-0.022 \\
(0.024)\end{array}$ & $\begin{array}{c}-0.018 \\
(0.027)\end{array}$ & $\begin{array}{c}0.010 \\
(0.031)\end{array}$ & $\begin{array}{c}-0.068 \\
(0.063)\end{array}$ \\
\hline Biweekly pay $\times$ Day of housing payment & $\begin{array}{l}-0.090^{* * *} \\
(0.030)\end{array}$ & $\begin{array}{c}-0.149^{* *} \\
(0.061)\end{array}$ & $\begin{array}{r}-0.106^{*} \\
(0.059)\end{array}$ & $\begin{array}{c}-0.053 \\
(0.042)\end{array}$ & $\begin{array}{c}-0.103^{* *} \\
(0.042)\end{array}$ & $\begin{array}{c}-0.072 \\
(0.060)\end{array}$ & $\begin{array}{c}-0.137 \\
(0.088)\end{array}$ \\
\hline Biweekly pay $\times 1-3$ days after housing payment & $\begin{array}{c}0.002 \\
(0.020)\end{array}$ & $\begin{array}{c}0.071^{*} \\
(0.041)\end{array}$ & $\begin{array}{r}-0.032 \\
(0.038)\end{array}$ & $\begin{array}{c}-0.013 \\
(0.028)\end{array}$ & $\begin{array}{c}0.012 \\
(0.028)\end{array}$ & $\begin{array}{c}-0.026 \\
(0.039)\end{array}$ & $\begin{array}{c}0.010 \\
(0.063)\end{array}$ \\
\hline Biweekly pay $\times 4-6$ days after housing payment & $\begin{array}{c}0.009 \\
(0.022)\end{array}$ & $\begin{array}{c}0.053 \\
(0.045)\end{array}$ & $\begin{array}{c}-0.042 \\
(0.042)\end{array}$ & $\begin{array}{c}-0.003 \\
(0.031)\end{array}$ & $\begin{array}{c}0.011 \\
(0.032)\end{array}$ & $\begin{array}{c}-0.047 \\
(0.041)\end{array}$ & $\begin{array}{l}0.043 \\
(0.070)\end{array}$ \\
\hline Monthly pay $\times$ Day of housing payment & $\begin{array}{c}-0.075 \\
(0.051)\end{array}$ & $\begin{array}{r}-0.199^{*} \\
(0.109)\end{array}$ & $\begin{array}{c}-0.095 \\
(0.097)\end{array}$ & $\begin{array}{c}-0.091 \\
(0.075)\end{array}$ & $\begin{array}{c}-0.038 \\
(0.070)\end{array}$ & $\begin{array}{r}-0.109 \\
(0.114)\end{array}$ & $\begin{array}{c}-0.115 \\
(0.120)\end{array}$ \\
\hline Monthly pay $\times 1-3$ days after housing payment & $\begin{array}{c}-0.002 \\
(0.034)\end{array}$ & $\begin{array}{l}0.140^{* *} \\
(0.070)\end{array}$ & $\begin{array}{c}-0.068 \\
(0.065)\end{array}$ & $\begin{array}{c}0.018 \\
(0.051)\end{array}$ & $\begin{array}{c}-0.016 \\
(0.045)\end{array}$ & $\begin{array}{c}-0.027 \\
(0.068)\end{array}$ & $\begin{array}{c}-0.012 \\
(0.081)\end{array}$ \\
\hline Monthly pay $\times 4-6$ days after housing payment & $\begin{array}{c}-0.010 \\
(0.038) \\
\end{array}$ & $\begin{array}{c}0.130 \\
(0.084) \\
\end{array}$ & $\begin{array}{c}-0.073 \\
(0.070)\end{array}$ & $\begin{array}{c}0.041 \\
(0.055)\end{array}$ & $\begin{array}{c}-0.054 \\
(0.053)\end{array}$ & $\begin{array}{c}0.005 \\
(0.082)\end{array}$ & $\begin{array}{c}0.018 \\
(0.094)\end{array}$ \\
\hline Day of the week & yes & yes & yes & yes & yes & yes & yes \\
\hline Day of the survey & yes & yes & yes & yes & yes & yes & yes \\
\hline Week of the calendar month & yes & yes & yes & yes & yes & yes & yes \\
\hline Number of observations & 252,531 & 62,824 & 63,222 & 115,502 & 137,029 & 54,762 & 44,748 \\
\hline Number of households & 18,574 & 4,608 & 4,662 & 8,496 & 10,078 & 4,033 & 3,312 \\
\hline Mean daily expenditures & 18.16 & 20.85 & 15.45 & 14.53 & 21.34 & 11.19 & 28.62 \\
\hline Fraction nonzero expenditures & 0.67 & 0.70 & 0.62 & 0.63 & 0.70 & 0.56 & 0.76 \\
\hline Adjusted R-squared & 0.24 & 0.23 & 0.25 & 0.26 & 0.21 & 0.25 & 0.19 \\
\hline
\end{tabular}

Each column is an OLS regression with household fixed effects. The dependent variable is transformed using the inverse hyperbolic sine, and trimmed at the 98 th percentile. The dummy variable ' $1-3$ days after housing payment' takes on value one for the first three days after a household pays rent or mortgage, and '4-6 days after housing payment' the three days following. All regressions contain controls for day of the week, day of the survey, and week of the month. Household income is total household income before taxes. Robust standard errors (in parentheses) are clustered at the household level. $* / * * / * * *$ correspond to $10 \% / 5 \% / 1 \%$ significance level.

\subsection{Robustness}

In Tables 6 7 I explore the robustness of the findings among two dimensions. First I split the sample by two-earner and one-earner couples. Two-earner couples could potentially face difficulty managing two different paycheck streams with a monthly housing payment, e.g. a weekly and a biweekly paycheck with a monthly housing payment. Reassuringly I find that the differences are small between the two. Non-durable spending increases with $48.8 \%$ for two-earner couples and with $47.5 \%$ for single earner couples on the day of the housing payment. Total food spending is even closer, $39.1 \%$ and $39.2 \%$. In the final three columns I split the sample by the day of the calendar month when a housing payment is made. The concern is that there could be some differences between households paying on the first of the month (or close to the first), and households paying in the middle of the month. Note that I do not observe whether a payment is due on a certain day. It is not the cases the housing payments made on a different than than the first of the month are late. Baugh et al. (2017) report quite a bit of heterogeneity in actual due dates over the course of the month, using data from a web aggregator. In Table 6 I find that households 
with a payment on the first of the month have a smaller spending response to the housing payment, compared to the households in the 8-day window around the first of the calendar month (but excluding the first of the month). Households paying rent or mortgage on any other day in the middle of the month (column 3) have the largest spending response $(+56.8 \%)$. The difference between households paying around the first of the month and any other day of the month is not that large though, both are sizable responses. Similar results hold for other spending categories, Tables A7A10. Note again that there are hardly any differences between weekly, biweekly and monthly paid.

Table 6: Robustness: Non-Durable Expenditures After Housing Payments

\begin{tabular}{|c|c|c|c|c|c|}
\hline & \multicolumn{2}{|c|}{ Earner Composition } & \multicolumn{3}{|c|}{ Day of the Month of Housing Payment } \\
\hline & $\begin{array}{l}\text { Dual } \\
(1)\end{array}$ & $\begin{array}{l}\text { Single } \\
(2)\end{array}$ & $\begin{array}{l}\text { First of the Month } \\
\text { (3) }\end{array}$ & $\begin{array}{l}\text { Around the First } \\
\text { (4) }\end{array}$ & $\begin{array}{c}\text { Other Days } \\
(5)\end{array}$ \\
\hline Day of housing payment & $\begin{array}{l}0.488^{* * *} \\
(0.044)\end{array}$ & $\begin{array}{l}0.475^{* * *} \\
(0.029)\end{array}$ & $\begin{array}{l}0.166^{* *} \\
(0.067)\end{array}$ & $\begin{array}{l}0.471^{* * *} \\
(0.040)\end{array}$ & $\begin{array}{l}0.568^{* * *} \\
(0.035)\end{array}$ \\
\hline Housing payment: $1-3$ days after & $\begin{array}{c}0.013 \\
(0.031)\end{array}$ & $\begin{array}{l}0.039^{* *} \\
(0.020)\end{array}$ & $\begin{array}{c}0.011 \\
(0.047)\end{array}$ & $\begin{array}{c}0.027 \\
(0.026)\end{array}$ & $\begin{array}{c}0.026 \\
(0.024)\end{array}$ \\
\hline Housing payment: $4-6$ days after & $\begin{array}{c}-0.037 \\
(0.034)\end{array}$ & $\begin{array}{c}-0.021 \\
(0.022)\end{array}$ & $\begin{array}{c}-0.110^{* *} \\
(0.052)\end{array}$ & $\begin{array}{c}-0.027 \\
(0.030)\end{array}$ & $\begin{array}{c}-0.010 \\
(0.026)\end{array}$ \\
\hline Biweekly pay $\times$ Day of housing payment & $\begin{array}{c}-0.127^{* *} \\
(0.054)\end{array}$ & $\begin{array}{c}-0.032 \\
(0.037)\end{array}$ & $\begin{array}{c}0.021 \\
(0.084)\end{array}$ & $\begin{array}{c}-0.050 \\
(0.049)\end{array}$ & $\begin{array}{c}-0.098^{* *} \\
(0.044)\end{array}$ \\
\hline Biweekly pay $\times 1-3$ days after housing payment & $\begin{array}{c}-0.037 \\
(0.038)\end{array}$ & $\begin{array}{l}0.008 \\
(0.024)\end{array}$ & $\begin{array}{c}0.037 \\
(0.057)\end{array}$ & $\begin{array}{c}0.003 \\
(0.033)\end{array}$ & $\begin{array}{c}-0.017 \\
(0.029)\end{array}$ \\
\hline Biweekly pay $\times 4-6$ days after housing payment & $\begin{array}{c}0.007 \\
(0.041)\end{array}$ & $\begin{array}{c}-0.003 \\
(0.027)\end{array}$ & $\begin{array}{c}0.058 \\
(0.064)\end{array}$ & $\begin{array}{c}0.008 \\
(0.037)\end{array}$ & $\begin{array}{c}-0.020 \\
(0.032)\end{array}$ \\
\hline Monthly pay $\times$ Day of housing payment & $\begin{array}{c}-0.146 \\
(0.102)\end{array}$ & $\begin{array}{c}0.030 \\
(0.061)\end{array}$ & $\begin{array}{c}0.193 \\
(0.131)\end{array}$ & $\begin{array}{c}0.004 \\
(0.080)\end{array}$ & $\begin{array}{c}-0.082 \\
(0.081)\end{array}$ \\
\hline Monthly pay $\times 1-3$ days after housing payment & $\begin{array}{c}0.014 \\
(0.067)\end{array}$ & $\begin{array}{c}0.013 \\
(0.041)\end{array}$ & $\begin{array}{c}-0.010 \\
(0.085)\end{array}$ & $\begin{array}{c}0.053 \\
(0.054)\end{array}$ & $\begin{array}{c}-0.019 \\
(0.055)\end{array}$ \\
\hline Monthly pay $\times 4-6$ days after housing payment & $\begin{array}{c}-0.075 \\
(0.078)\end{array}$ & $\begin{array}{c}-0.018 \\
(0.046)\end{array}$ & $\begin{array}{c}0.061 \\
(0.109)\end{array}$ & $\begin{array}{c}-0.042 \\
(0.060)\end{array}$ & $\begin{array}{c}-0.054 \\
(0.060)\end{array}$ \\
\hline Day of the week & yes & yes & yes & yes & yes \\
\hline Day of the survey & yes & yes & yes & yes & yes \\
\hline Week of the calendar month & yes & yes & no & no & no \\
\hline Number of observations & 80,311 & 172,221 & 32,537 & 97,049 & 122,945 \\
\hline Number of households & 5,911 & 12,663 & 2,390 & 7,176 & 9,008 \\
\hline Mean daily expenditures & 32.76 & 23.06 & 23.75 & 25.15 & 27.50 \\
\hline Fraction nonzero expenditures & 0.78 & 0.71 & 0.72 & 0.72 & 0.73 \\
\hline Adjusted R-squared & 0.21 & 0.24 & 0.22 & 0.24 & 0.24 \\
\hline
\end{tabular}

Each column is an OLS regression with household fixed effects. The dependent variable is transformed using the inverse hyperbolic sine, and trimmed at the 98th percentile. The dummy variable ' $1-3$ days after housing payment' takes on value one for the first three days after a household pays rent or mortgage, and '4-6 days after housing payment' the three days following. In column (3) only households are selected who make a housing payment on the first of the month. In column (4) households who pay within a window of eight days around the first of the month: four days before the 1st, and four days after (the first is not included). Column (5) reports results for households with housing payments on all other days of the month. All regressions contain controls for day of the week, day of the survey, and week of the month. Robust standard errors (in parentheses) are clustered at the household level. */**/*** correspond to 10\%/5\%/1\% significance level. 
Table 7: Robustness: Total Food Expenditures After Housing Payments

\begin{tabular}{|c|c|c|c|c|c|}
\hline & Earner & omposition & Day of the & Month of Housing & avment \\
\hline & $\begin{array}{l}\text { Dual } \\
\text { (1) }\end{array}$ & $\begin{array}{c}\text { Single } \\
(2)\end{array}$ & $\begin{array}{l}\text { First of the Month } \\
\text { (3) }\end{array}$ & $\begin{array}{l}\text { Around the First } \\
\text { (4) }\end{array}$ & $\begin{array}{c}\text { Other Days } \\
(5)\end{array}$ \\
\hline Day of housing payment & $0.391^{* * *}$ & $0.392^{* * *}$ & $0.116^{*}$ & $0.373^{* * *}$ & $0.473^{* * *}$ \\
\hline & $(0.044)$ & $(0.029)$ & $(0.065)$ & $(0.039)$ & $(0.035)$ \\
\hline Housing payment: $1-3$ days after & 0.013 & $0.041^{* *}$ & 0.015 & 0.014 & 0.036 \\
\hline & $(0.030)$ & $(0.019)$ & $(0.046)$ & $(0.026)$ & $(0.022)$ \\
\hline Housing payment: 4-6 days after & -0.034 & -0.021 & $-0.151^{* * *}$ & -0.010 & -0.016 \\
\hline & $(0.033)$ & $(0.021)$ & $(0.050)$ & $(0.029)$ & $(0.025)$ \\
\hline Biweekly pay $\times$ Day of housing payment & $-0.140^{* * *}$ & $-0.062^{*}$ & 0.014 & -0.063 & $-0.130^{* * *}$ \\
\hline & $(0.054)$ & $(0.036)$ & $(0.081)$ & $(0.048)$ & $(0.043)$ \\
\hline Biweekly pay $\times 1-3$ days after housing payment & -0.030 & 0.016 & 0.023 & 0.007 & -0.002 \\
\hline & $(0.037)$ & $(0.024)$ & $(0.057)$ & $(0.032)$ & $(0.028)$ \\
\hline Biweekly pay $\times 4-6$ days after housing payment & 0.007 & 0.012 & $0.109^{*}$ & -0.002 & -0.002 \\
\hline & $(0.040)$ & $(0.026)$ & $(0.062)$ & $(0.036)$ & $(0.031)$ \\
\hline Monthly pay $\times$ Day of housing payment & $-0.192^{*}$ & -0.042 & 0.096 & -0.091 & -0.095 \\
\hline & $(0.102)$ & $(0.059)$ & $(0.120)$ & $(0.080)$ & $(0.080)$ \\
\hline Monthly pay $\times 1-3$ days after housing payment & -0.006 & -0.0001 & -0.028 & 0.040 & -0.025 \\
\hline & $(0.065)$ & $(0.039)$ & $(0.083)$ & $(0.053)$ & $(0.052)$ \\
\hline Monthly pay $\times 4-6$ days after housing payment & -0.001 & -0.022 & 0.130 & -0.031 & -0.034 \\
\hline & $(0.075)$ & $(0.044)$ & $(0.101)$ & $(0.058)$ & $(0.060)$ \\
\hline Day of the week & yes & yes & yes & yes & yes \\
\hline Day of the survey & yes & yes & yes & yes & yes \\
\hline Week of the calendar month & yes & yes & no & no & no \\
\hline Number of observations & 80,311 & 172,221 & 32,537 & 97,049 & 122,945 \\
\hline Number of households & 5,911 & 12,663 & 2,390 & 7,176 & 9,008 \\
\hline Mean daily expenditures & 22.93 & 15.99 & 16.55 & 17.58 & 19.06 \\
\hline Fraction nonzero expenditures & 0.72 & 0.64 & 0.65 & 0.66 & 0.67 \\
\hline Adjusted R-squared & 0.22 & 0.24 & 0.23 & 0.25 & 0.24 \\
\hline
\end{tabular}

Each column is an OLS regression with household fixed effects. The dependent variable is transformed using the inverse hyperbolic sine, and trimmed at the 98th percentile. The dummy variable ' $1-3$ days after housing payment' takes on value one for the first three days after a household pays rent or mortgage, and '4-6 days after housing payment' the three days following. In column (3) only households are selected who make a housing payment on the first of the month. In column (4) households who pay within a window of eight days around the first of the month: four days before the 1st, and four days after (the first is not included). Column (5) reports results for households with housing payments on all other days of the month. All regressions contain controls for day of the week, day of the survey, and week of the month. Robust standard errors (in parentheses) are clustered at the household level. $* / * * / * * *$ correspond to $10 \% / 5 \% / 1 \%$ significance level.

\section{Quasi-Experimental Evidence}

Having established that households increase nondurable spending after housing payments are made, one question is how these households would respond to receiving extra cashat-hand. To explore this, I focus on workers with a biweekly pay schedule. Biweekly paid households receive a paycheck every other week, typically on a Friday. This means that biweekly paid workers receive 26 paychecks in a year, and need to pay 12 housing payments. Though a biweekly pay schedule is very regular, there is a difference in timing with monthly housing payments. Specifically, in a calendar year there are 10 housing 
payments to be made with 2 paychecks, and 2 housing payments with 3 paychecks. 8 I will compare episodes between two housing payments with three paychecks to episodes between housing payments with two paychecks. First I will investigate the consumption response to these "third" paychecks. A consumption response to anticipated paychecks would be in line with liquidity constrained or hand-to-mouth consumers. Then I compare the days after the housing payment is made in episodes with a "third check" to episodes with two checks. If liquidity constraints is the main explanation for the pattern of household spending around the day of the housing payment, then extra cash-on-hand should alleviate this pattern (by definition a third check is always received before the housing payment is made).

It is important to note that these "third checks" are anticipated from the perspective of the worker. In principle the household can schedule receipt of paychecks and housing payments at the beginning of the calendar year. The size of the income payment is not trivial: a third check constitutes $\frac{1}{13}$ th or $7.7 \%$ of annual wage income. In the data the average paycheck of a biweekly paid worker is comparable to the average tax refund received (see also Souleles (1999)). Tax refunds though are reimbursed once a year, where biweekly earners receive twice a year a third check (and not all wage earners receive a tax refund).

In the data I do observe the frequency of paycheck receipt, but not the actual date of payment, a problem I share with Zhang (2017). Biweekly paid households can be on one of two different pay schedules, "even Fridays" or "odd Fridays". I create a dummy variable for the 14 days after a third check in between two housing payments. There are two sources of measurement error in this dummy variable. The first is that I assign households to the wrong biweekly pay schedule: a worker is paid on even Fridays, where I assign her on odd Fridays. Since the independent variable is a dummy variable, this generates a downward bias of the regression coefficient (see appendix B in Zhang (2017) for a derivation). The downward bias in the coefficients is approximately $50 \%$ if the proportions of workers on the two pay schedules are approximately equal..$^{9}$ I do not correct the coefficients or the standard errors for the downward bias. A second source of measurement error is that only one housing payment is observed for each household. Here I make the assumption that a household pays the housing payment on the same day in the previous month. If the households paid earlier in the previous month, I would assign households to a two-check episode, where this could be a three-check episode. If the household paid later, I would assign households to a three-check episode, where this could be a two-check episode. This potential misclassification generates the same type of measurement error, and also biases the coefficients downwards. As a consequence, I am careful to over-interpret the results. To facilitate readability, I construct a dummy variable taking value one for the seven days

8 Thaler and Sunstein (2008) describe this phenomenon, Zhang (2017) uses the quarterly version of the CEX to construct a test of excess sensitivity. An important difference with this study is that she assigns periods with three checks by aggregating the number of paychecks by calendar month, where I count how many checks are being received between two housing payments. For households paying rent on the 1st of the month, the two schedules are virtually the same, but not for households paying later in the month (e.g. on the 15th).

${ }^{9}$ Calculations on the open data of Gelman et al. (2014) suggest that Friday is by far the most common payday for biweekly paid workers, and the fraction of workers on each schedule is indeed around 0.5 . 
after the housing payment (including the day of housing payment) and zero otherwise. All specifications include household fixed effects, dummies for day of the week, day of the survey and week of the calendar month. Only households with a single biweekly earner are selected, to reduce the interference of other paycheck frequencies within dual-earner households. Monthly earners from one-earner households are added as a control group to control for contemporaneous time effects-there is variation between the years when biweekly paid receive a third check, but little variation within the year. Results are very similar without a control group, or when dual wage earners are included.

Table 8: Quasi-Experimental Variation in Cash-at-Hand for Biweekly Paid Households

\begin{tabular}{|c|c|c|c|c|c|c|}
\hline & $\begin{array}{c}\text { Nondurable } \\
\text { (1) }\end{array}$ & $\begin{array}{l}\text { All Food } \\
\text { (2) }\end{array}$ & $\begin{array}{c}\text { Food at Home } \\
\text { (3) }\end{array}$ & $\begin{array}{c}\text { Food Away } \\
\text { (4) }\end{array}$ & $\begin{array}{c}\text { Instant } \\
(5)\end{array}$ & $\begin{array}{l}\text { Fresh Food } \\
\text { (6) }\end{array}$ \\
\hline $\begin{array}{l}\text { Panel A. } \\
\text { Third check }\end{array}$ & $\begin{array}{l}0.104^{* * *} \\
(0.025)\end{array}$ & $\begin{array}{l}0.093^{* * *} \\
(0.025)\end{array}$ & $\begin{array}{l}0.088^{* * *} \\
(0.023)\end{array}$ & $\begin{array}{l}0.048^{* *} \\
(0.021)\end{array}$ & $\begin{array}{l}0.062^{* * *} \\
(0.022)\end{array}$ & $\begin{array}{l}0.053^{* * *} \\
(0.012)\end{array}$ \\
\hline $\begin{array}{l}\text { Panel B. } \\
0-6 \text { days after housing payment }\end{array}$ & $\begin{array}{l}0.104^{* * *} \\
(0.014)\end{array}$ & $\begin{array}{l}0.085^{* * *} \\
(0.013)\end{array}$ & $\begin{array}{l}0.080^{* * *} \\
(0.012)\end{array}$ & $\begin{array}{l}0.043^{* * *} \\
(0.011)\end{array}$ & $\begin{array}{l}0.055^{* * *} \\
(0.011)\end{array}$ & $\begin{array}{l}0.039^{* * *} \\
(0.006)\end{array}$ \\
\hline Third check & $\begin{array}{l}0.066^{* *} \\
(0.030)\end{array}$ & $\begin{array}{l}0.058^{* *} \\
(0.029)\end{array}$ & $\begin{array}{l}0.055^{* *} \\
(0.028)\end{array}$ & $\begin{array}{c}0.040 \\
(0.024)\end{array}$ & $\begin{array}{c}0.048^{*} \\
(0.025)\end{array}$ & $\begin{array}{l}0.039^{* * *} \\
(0.015)\end{array}$ \\
\hline Third check $\times 0$ 0-6 days after housing payment & $\begin{array}{c}-0.029 \\
(0.028)\end{array}$ & $\begin{array}{c}-0.017 \\
(0.026)\end{array}$ & $\begin{array}{c}-0.018 \\
(0.025)\end{array}$ & $\begin{array}{c}-0.022 \\
(0.023)\end{array}$ & $\begin{array}{c}-0.023 \\
(0.023)\end{array}$ & $\begin{array}{c}-0.012 \\
(0.014)\end{array}$ \\
\hline Panel C. & & & & & & \\
\hline 0-6 days after housing payment & $\begin{array}{l}0.104^{* * *} \\
(0.014)\end{array}$ & $\begin{array}{l}0.085^{* * *} \\
(0.013)\end{array}$ & $\begin{array}{l}0.080^{* * *} \\
(0.012)\end{array}$ & $\begin{array}{l}0.043^{* * *} \\
(0.011)\end{array}$ & $\begin{array}{l}0.055^{* * *} \\
(0.011)\end{array}$ & $\begin{array}{l}0.039^{* * *} \\
(0.006)\end{array}$ \\
\hline Third check & $\begin{array}{l}0.067^{* *} \\
(0.030)\end{array}$ & $\begin{array}{l}0.058^{* *} \\
(0.029)\end{array}$ & $\begin{array}{l}0.055^{* *} \\
(0.028)\end{array}$ & $\begin{array}{c}0.040 \\
(0.024)\end{array}$ & $\begin{array}{c}0.048^{*} \\
(0.025)\end{array}$ & $\begin{array}{l}0.039^{* * *} \\
(0.015)\end{array}$ \\
\hline Third check $\times 0$ - 6 days after housing payment & $\begin{array}{c}0.024 \\
(0.033)\end{array}$ & $\begin{array}{c}0.020 \\
(0.032)\end{array}$ & $\begin{array}{c}0.008 \\
(0.031)\end{array}$ & $\begin{array}{c}0.003 \\
(0.028)\end{array}$ & $\begin{array}{c}0.009 \\
(0.029)\end{array}$ & $\begin{array}{c}-0.001 \\
(0.017)\end{array}$ \\
\hline $\begin{array}{l}\text { Third check } \times 0-6 \text { days after housing payment } \\
\times \text { above median budget share housing }\end{array}$ & $\begin{array}{l}-0.111^{* * *} \\
(0.040)\end{array}$ & $\begin{array}{c}-0.077^{* *} \\
(0.039)\end{array}$ & $\begin{array}{r}-0.052 \\
(0.036)\end{array}$ & $\begin{array}{r}-0.052 \\
(0.034)\end{array}$ & $\begin{array}{r}-0.066^{*} \\
(0.035)\end{array}$ & $\begin{array}{c}-0.024 \\
(0.020)\end{array}$ \\
\hline Day of the week & yes & yes & yes & yes & yes & yes \\
\hline Day of the survey & yes & yes & yes & yes & yes & yes \\
\hline Week of the calender month & yes & yes & yes & yes & yes & yes \\
\hline Mean daily expenditures & 23.15 & 16.14 & 8.33 & 6.46 & 7.28 & 1.20 \\
\hline Fraction nonzero expenditures & 0.71 & 0.65 & 0.34 & 0.49 & 0.50 & 0.19 \\
\hline
\end{tabular}

Each column is an OLS regression with household fixed effects. The dependent variable is transformed using the inverse hyperbolic sine, and trimmed at the 98th percentile. The dummy variable Third Check takes on value one for the first 14 days after a household receives a third check between two housing payments (including the day of payment) Dummy variable "0-6 days after housing payment" takes value one for the day of the rent/mortgage payment and the six following days. Only single wage earners are selected, and all panels use monthly paid households as a control group. Total number of observations in each panel is 114,775 for 8,434 households. All regressions contain controls for day of the week, day of the survey, and week of the calendar month. Robust standard errors (in parentheses) are clustered at the household level. */**/*** correspond to $10 \% / 5 \% / 1 \%$ significance level.

Results of three specifications are presented in Table 8. Panel A shows how nondurable spending responds in the 14 days after receiving a third check. Nondurable spending increases with 10 percent in the 14 days after a third check. Total food spending increases with 9.3 percent, mostly coming from expenditures of food at home (8.8\%) and less so 
from food away from home (4.8\%). Also measures closer to actual consumption respond: instant consumption increases with $6.2 \%$ and fresh food expenditures with $5.3 \% .10$ The finding that biweekly paid households respond to "extra" cash-at-hand suggests that many households are liquidity constrained.

In Panel B. a dummy is added for the day of the housing payment and the six days after. The qualitative pattern as documented in Table 3 is replicated: non-durable spending increases on average with $10 \%$ after the housing payments are made, and $8.5 \%$ for total food spending. Comparing the coefficients on variable Third Check between Panel A. and Panel B. one can see that some of the response to receiving a third check is picked up by the housing payment effect. For example, non-durable spending decreases from $10.4 \%$ in Panel A. to $6.6 \%$ in Panel B. To some extent this is by construction. The extra check is defined as the third check in between two housing payments, and so will be 1-3 days before the next housing payment. The week after the housing payment is thus always included in the 14-day period of the third check. However, in Panel B. the increase of $6.6 \%$ in non-durable spending is the average for the entire 14-day period, that is after controlling for the week of the housing payment. In Panel B. also the interaction variable is included between receiving a third check and the week after housing payment. All signs are negative, suggesting that in periods when the household receives extra cash-on-hand, non-durable spending around the housing payment decreases. The coefficients are small, with large standard errors, and none of the coefficients on the interaction term are statistically significant from zero. This is likely due to the measurement error due to misclassification of the dummy variable Third Check. Measurement error not only biases downward the estimates on the interaction term, but also affects the standard errors.

In Panel C. there is some suggestive evidence that the interaction effect in Panel B. masks a heterogeneous effect. The interaction term is again interacted with a dummy variable, which takes value one if households have a relatively large budget share of housing and zero otherwise. The median budget share is taken as the cut-off. Findings are reported in the last line of panel C. In periods with a third check households with a large budget share of housing reduce non-durable spending in the week after making the housing payment. Effect sizes for this sub-group are considerable. For example, non-durable spending is $11.1 \%$ lower during episodes with an extra check, compared to normal times with two checks. Total food spending decreases with $7.7 \%$. The two underlying components of total food spending, food at home and food away, carry both negative signs, and the point estimates are sizable, though not statistically significant from zero. Instant consumption decreases with $6.6 \%$, and fresh food with $2.4 \%$ (though not statistically significant). Households with a relatively low budget share of housing (the reference group) show little response-

\footnotetext{
10 Zhang (2017) does not find a response of strict non-durable spending or food spending in the month after a three check month. There are a few possible explanations for these differences in findings. First, Zhang (2017) constructs episodes with three paychecks based on a within-month count of paychecks, where this study argues that the relevant period for the household is between two housing payments. When I construct the variable Third Check in the same way as Zhang, coefficients are much smaller and statistically insignificant. Second, the diary survey is much better suited to measure strict non-durable spending and food consumption than the CEX quarterly data (Attanasio, Battistin and Ichimura, 2007).
} 
estimated coefficients are close to zero with large standard errors.

Taken together, there are three pieces of suggestive evidence that liquidity constraints is the main explanation. First, households increase non-durable and food spending the week after housing payments are made. Second, on days with an expected "extra" paycheck, biweekly paid households increase spending. Both the response and the modest size of the response are similar to other studies using tax returns (Souleles, 1999; Baugh et al., 2018). Thirdly, households with a large budget share of housing seem to decrease non-durable spending in the week after the housing payment is made. The first two findings can be explained by liquidity constraints. The third finding points to an important interaction between liquidity constraints and the share of consumption commitments in the household budget for the timing of non-durable expenditures. Due to the potential misclassification issues, the results of this exercise need to be interpreted with caution, but the core idea would be an interesting avenue for future research.

\section{Conclusions}

Using the daily portion of the CEX diary survey, I document a new empirical finding: households take the date of large, pre-committed expenditures into account when they time non-durable spending and food consumption. This finding is unrelated to the frequency of pay, which suggests that households respond more to the timing of large, fixed expenditures than to the arrival of income. Responses to the pattern of committed expenditure are easily confounded with the timing of income streams: what seems to be a consumption response to income, actually is a response to housing payments. Moreover, the spending response around housing payments is larger than the reported spending response to income receipt reported in the literature. The most likely candidate explanation is liquidity constraints, and in line with a growing body of evidence (Kaplan, Violante and Weidner, 2014), also middle-class and higher income households can be liquidity constrained (especially if the budget share of consumption commitments is constant over the middle income quintiles).

A first conclusion is that the structure of household expenditures could matter for fiscal and monetary policy, a point overlooked so far. In the context of income changes due to unemployment, Chetty (2004) mentions the potential importance of consumption commitments for determining the replacement rate of unemployment benefits. A second conclusion is that these findings suggest that any policy prescriptions for altering the timing of income payments should also take account of the impact of consumption commitments on consumer spending and welfare. For example, Parsons and Wesep (2013) suggest that increasing the frequency of paychecks could be a welfare improvement if consumers are hyperbolic discounters. Given that I find that weekly, biweekly and monthly paid households respond in the same way to the timing of monthly housing payments, this is unlikely to be a welfare improvement. The lack of exogenous variation though does not allow me to draw strong conclusions with respect to this particular policy prescription. Finally, an interesting avenue for future research could be to explore the effects of housing subsidies as 
a policy instrument in recessions to provide liquidity, instead of blanket income transfers. Such a policy instrument could potentially be more effective in stimulating consumption, by taking into account a source of relevant heterogeneity in consumer spending.

\section{References}

Attanasio, Orazio, Erich Battistin, and Hidehiko Ichimura. 2007. "What Really Happened to Consumption Inequality in the United States?" In Hard-to-Measure Goods and Services: Essays in Honor of Zvi Griliches. 515-543. University of Chicago Press.

Baugh, Brian, Itzhak Ben-David, Hoonsuk Park, and Jonathan A Parker. 2018. "Asymmetric Consumption Response of Households to Positive and Negative Anticipated Cash Flows." National Bureau of Economic Research Working Paper 25086.

Baugh, Brian, Jesse B Leary, Financial Conduct Authority, and Jialan Wang. 2017. "When Is It Hard to Make Ends Meet?" Working Paper.

Browning, Martin, and M. Dolores Collado. 2001. "The Response of Expenditures to Anticipated Income Changes: Panel Data Estimates." American Economic Review, 91(3): 681-692.

Burbidge, John B., Lonnie Magee, and A. Leslie Robb. 1988. "Alternative Transformations to Handle Extreme Values of the Dependent Variable." Journal of the American Statistical Association, 83(401): 123.

Carvalho, Leandro S., Stephan Meier, and Stephanie W. Wang. 2016. "Poverty and Economic Decision-Making: Evidence from Changes in Financial Resources at Payday." American economic review, 106(2): 260-284.

Chetty, Raj. 2004. "Consumption commitments, unemployment durations, and local risk aversion." National Bureau of Economic Research.

Chetty, Raj, and Adam Szeidl. 2007. "Consumption Commitments and Risk Preferences." Quarterly Journal of Economics, 122(2): 831-877.

Chetty, Raj, and Adam Szeidl. 2010. "Consumption Commitments: A Foundation for Reference-Dependent Preferences and Habit Formation." Working Paper.

Dobkin, Carlos, and Steven L. Puller. 2007. "The Effects of Government Transfers on Monthly Cycles in Drug Abuse, Hospitalization and Mortality." Journal of Public Economics, 91(11-12): 2137-2157.

Evans, William N., and Timothy J. Moore. 2011. "The Short-Term Mortality Consequences of Income Receipt." Journal of Public Economics, 95(11 - 12): 1410 - 1424. Special Issue: International Seminar for Public Economics on Normative Tax Theory. 
Evans, William N., and Timothy J. Moore. 2012. "Liquidity, Economic Activity, and Mortality." Review of Economics and Statistics, 94(2): 400-418.

Gelman, Michael, Shachar Kariv, Matthew D. Shapiro, Dan Silverman, and Steven Tadelis. 2015. "How Individuals Smooth Spending: Evidence from the 2013 Government Shutdown Using Account Data." National Bureau of Economic Research Working Paper 21025.

Gelman, M., S. Kariv, M. D. Shapiro, D. Silverman, and S. Tadelis. 2014. "Harnessing Naturally Occurring Data to Measure the Response of Spending to Income." Science, 345(6193): 212-215.

Hastings, Justine, and Ebonya Washington. 2010. "The First of the Month Effect: Consumer Behavior and Store Responses." American Economic Journal: Economic Policy, 2(2): 142-62.

Kaplan, Greg, and Giovanni L. Violante. 2014. "A Model of the Consumption Response to Fiscal Stimulus Payments." Econometrica, 82(4): 1199-1239.

Kaplan, Greg, Giovanni Violante, and Justin Weidner. 2014. "The Wealthy Handto-Mouth." Brookings Papers on Economic Activity, 1: 77-138.

Lusardi, Annamaria. 1996. "Permanent Income, Current Income, and Consumption: Evidence from Two Panel Data Sets." Journal of Business 86 Economic Statistics, 14(1): 81-90.

Mastrobuoni, Giovanni, and Matthew Weinberg. 2009. "Heterogeneity in Intramonthly Consumption Patterns, Self-Control, and Savings at Retirement." American Economic Journal: Economic Policy, 1(2): 163-89.

Misra, Kanishka, and Paolo Surico. 2014. "Consumption, income changes, and heterogeneity: Evidence from two fiscal stimulus programs." American Economic Journal: Macroeconomics, 6(4): 84-106.

Ni, Shawn, and Youn Seol. 2014. "New evidence on excess sensitivity of household consumption." Journal of Monetary Economics, 63: 80-94.

Parker, Jonathan A., Nicholas S. Souleles, David S. Johnson, and Robert McClelland. 2013. "Consumer Spending and the Economic Stimulus Payments of 2008." American Economic Review, 103(6): 2530-2553.

Parsons, Christopher A., and Edward D. Van Wesep. 2013. "The Timing of Pay." Journal of Financial Economics, 109(2): 373-397.

Postlewaite, Andrew, Larry Samuelson, and Dan Silverman. 2008. "Consumption Commitments and Employment Contracts." Review of Economic Studies, 75(2): 559578. 
Shapiro, Jesse M. 2005. "Is There a Daily Discount Rate? Evidence From the Food Stamp Nutrition Cycle." Journal of Public Economics, 89(2-3): 303-325.

Shore, Stephen H., and Todd Sinai. 2010. "Commitment, Risk, and Consumption: Do Birds of a Feather Have Bigger Nests?" The Review of Economics and Statistics, 92(2): 408-424.

Souleles, Nicholas S. 1999. "The Response of Household Consumption to Income Tax Refunds." American Economic Review, 89(4): 947-958.

Stephens Jr., Melvin. 2003. "3rd of tha Month": Do Social Security Recipients Smooth Consumption Between Checks?" American Economic Review, 93(1): 406-422.

Telyukova, Irina A. 2013. "Household Need for Liquidity and the Credit Card Debt Puzzle." Review of Economic Studies, 80(3): 1148-1177.

Telyukova, Irina A, and Ludo Visschers. 2013. "Precautionary money demand in a business-cycle model." Journal of Monetary Economics, 60(8): 900-916.

Thaler, Richard H., and Cass R. Sunstein. 2008. Nudge: Improving Decisions about Health, Wealth, and Happiness. Yale University Press.

Zhang, C Yiwei. 2017. "Consumption Responses to Pay Frequency: Evidence from 'Extra' Paychecks." Working Paper. 


\section{Online Appendix-Not For Publication}

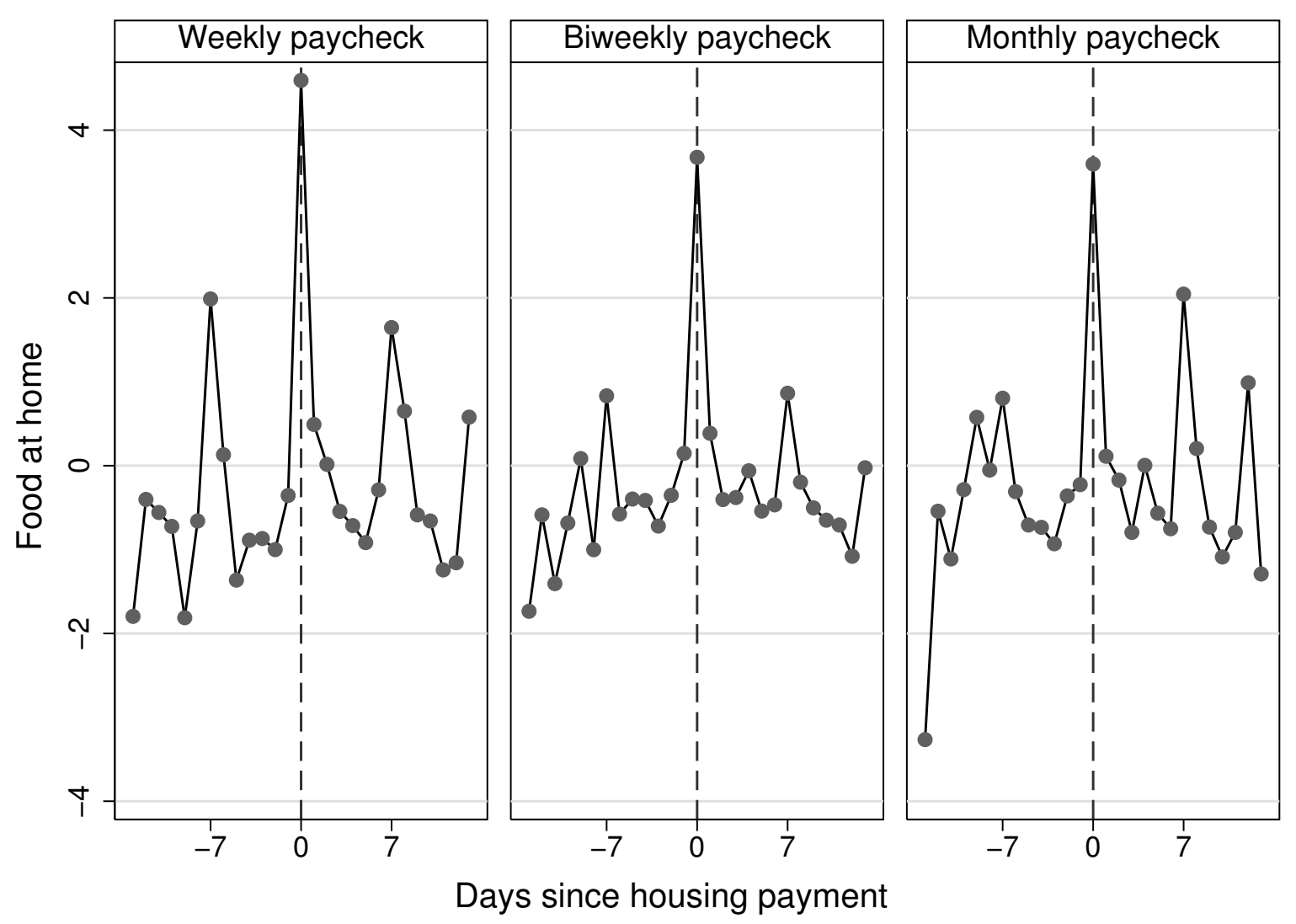

Figure A1: Daily Spending Around Housing Payment: Food at Home

Averaged residuals constructed from three separate regressions controlling for day of the week, day of survey, and day of the calendar month. 


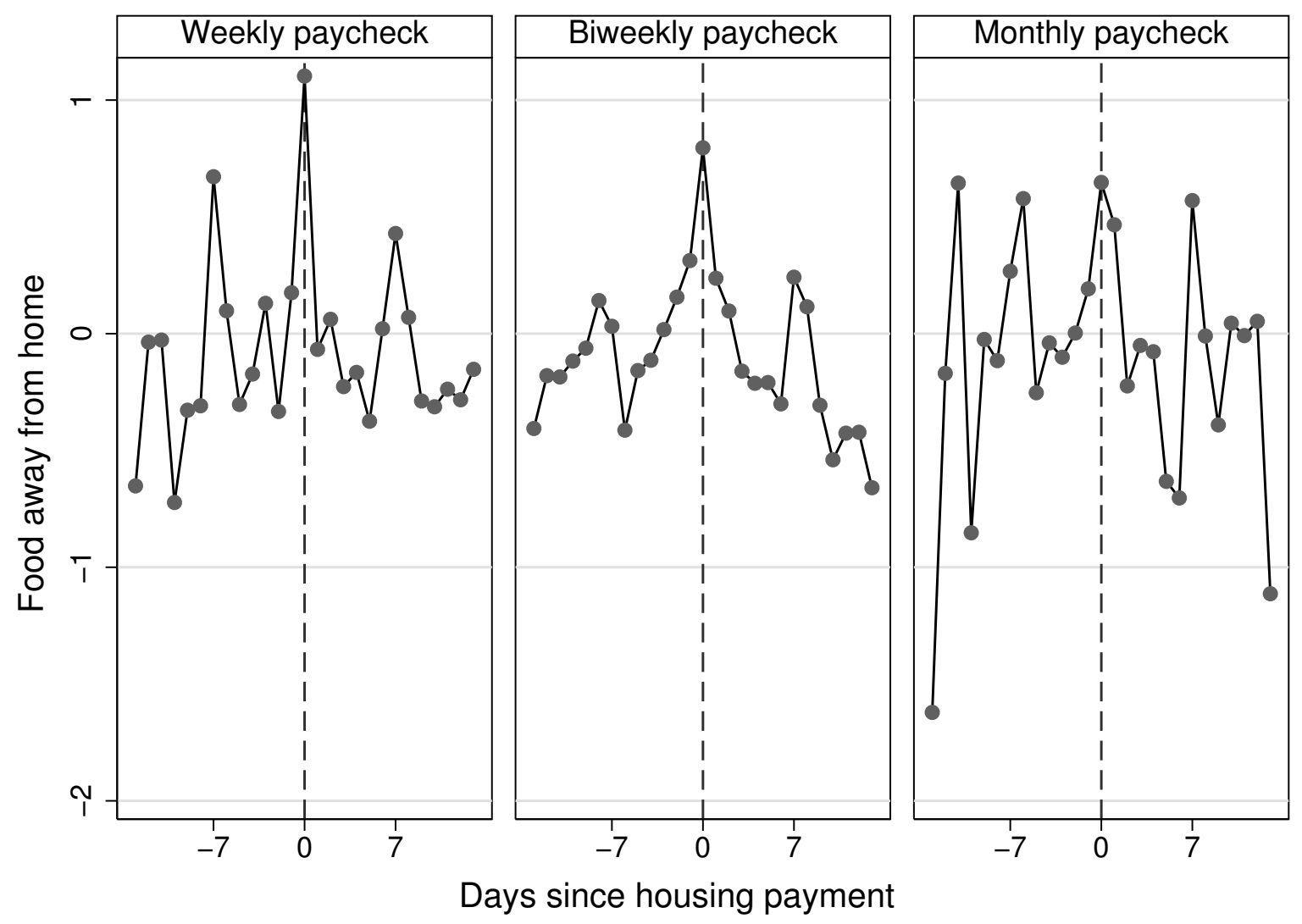

Figure A2: Daily Spending Around Housing Payment: Food Away from Home Averaged residuals constructed from three separate regressions controlling for day of the week, day of survey, and day of the calendar month. 

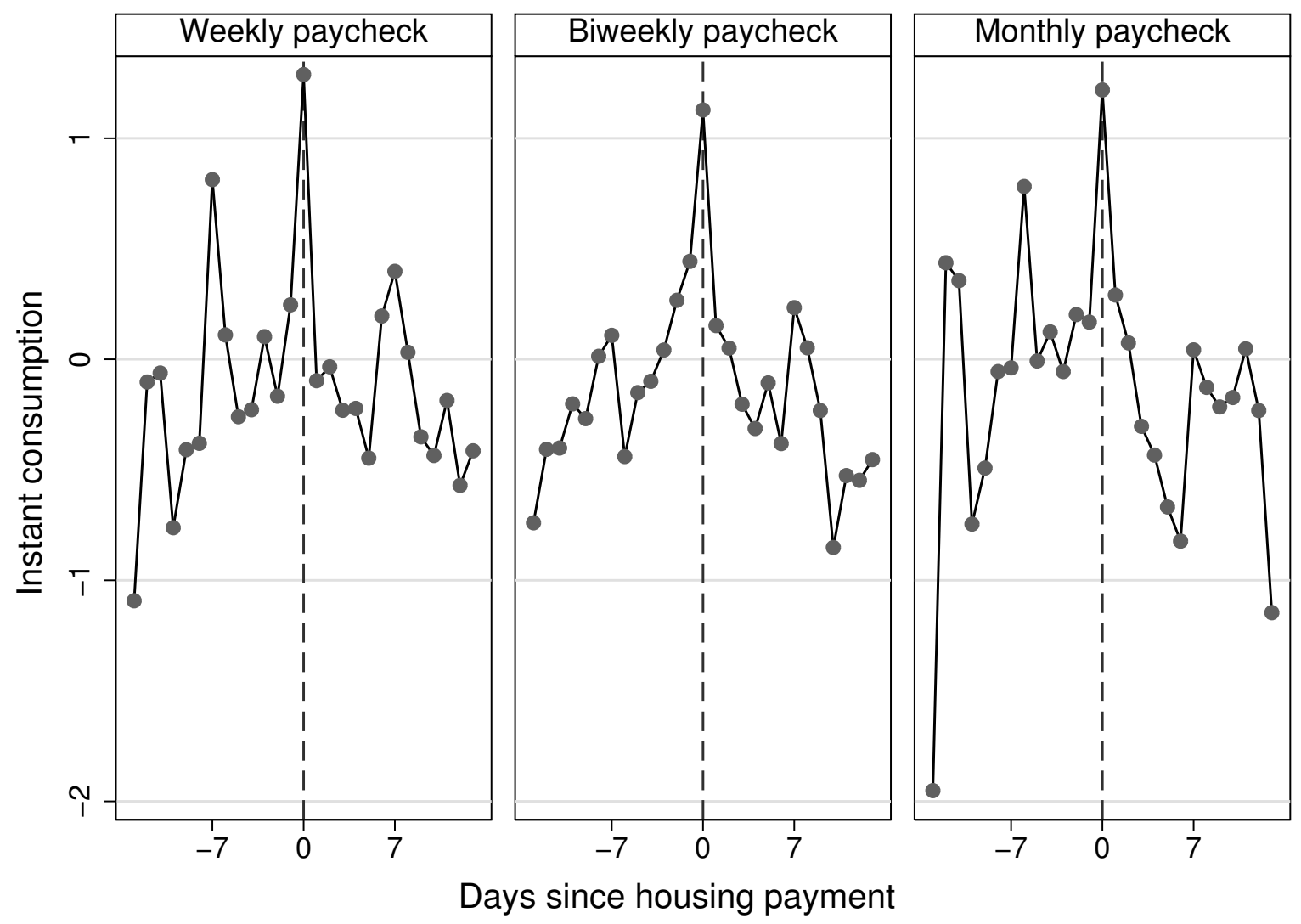

Figure A3: Daily Spending Around Housing Payment: Instant Consumption

Averaged residuals constructed from three separate regressions controlling for day of the week, day of survey, and day of the calendar month. 


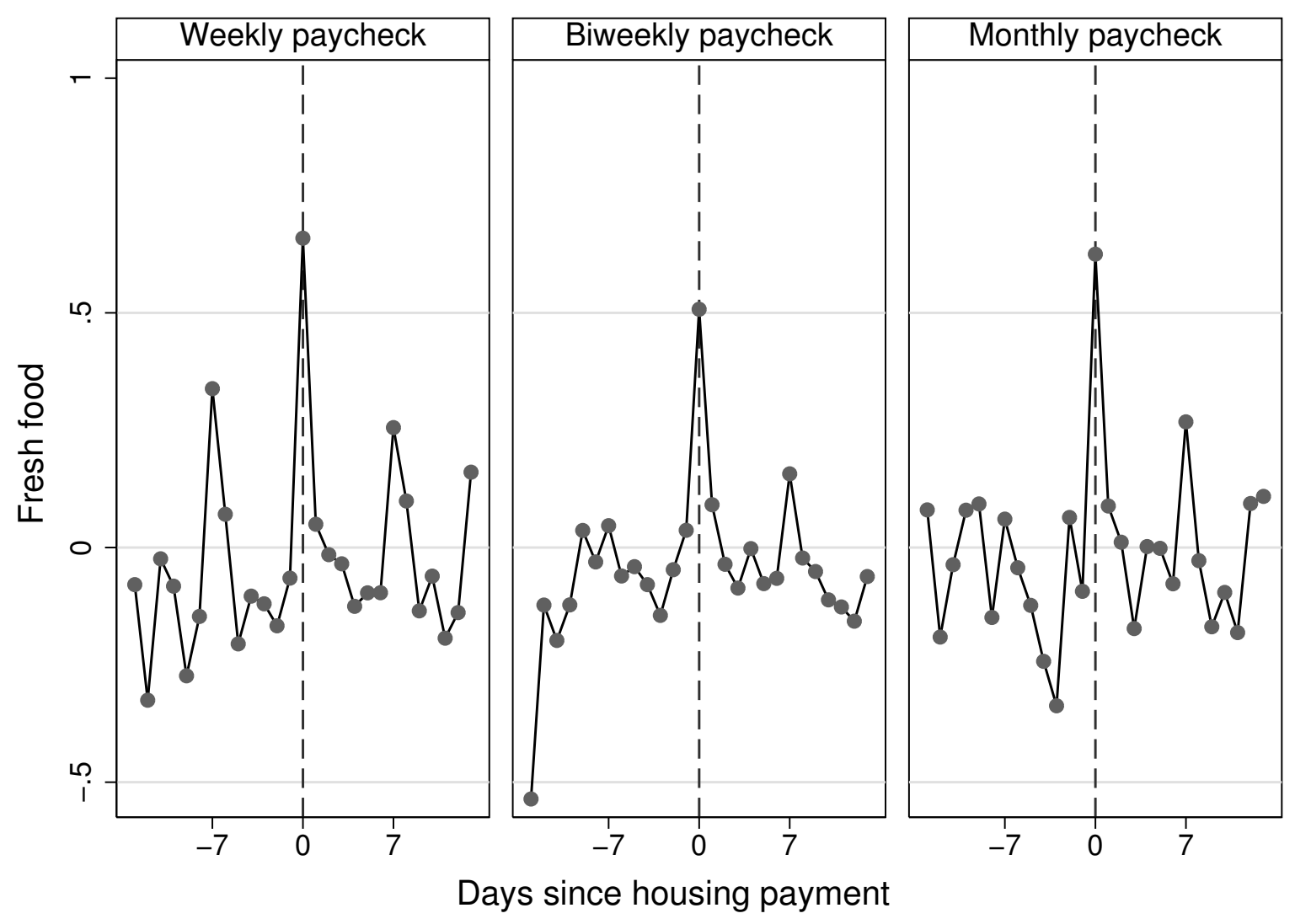

Figure A4: Daily Spending Around Housing Payment: Fresh Food

Averaged residuals constructed from three separate regressions controlling for day of the week, day of survey, and day of the calendar month. 
Table A1: Expenditures on Food at Home and Food Away After Housing Payment

\begin{tabular}{|c|c|c|c|c|c|c|}
\hline \multirow[b]{3}{*}{ Paycheck frequency } & \multicolumn{3}{|c|}{ A. Food at Home } & \multicolumn{3}{|c|}{ B. Food Away from Home } \\
\hline & (1) & $(2)$ & (3) & (1) & (2) & (3) \\
\hline & Weekly & Biweekly & Monthly & Weekly & Biweekly & Monthly \\
\hline \multirow[t]{2}{*}{ Day of housing payment } & $0.410^{* * *}$ & $0.329^{* * *}$ & $0.275^{* * *}$ & $0.183^{* * *}$ & $0.135^{* * *}$ & $0.130^{* * *}$ \\
\hline & $(0.026)$ & $(0.019)$ & $(0.049)$ & $(0.019)$ & $(0.015)$ & $(0.038)$ \\
\hline \multirow[t]{2}{*}{ Housing payment: $1-3$ days after } & $0.039^{* *}$ & $0.025^{* *}$ & -0.026 & 0.017 & $0.021^{* *}$ & 0.014 \\
\hline & $(0.016)$ & $(0.012)$ & $(0.029)$ & $(0.014)$ & $(0.011)$ & $(0.027)$ \\
\hline \multirow[t]{2}{*}{ Housing payment: 4-6 days after } & -0.028 & -0.011 & -0.032 & $-0.028^{*}$ & -0.010 & $-0.074^{* *}$ \\
\hline & $(0.017)$ & $(0.013)$ & $(0.034)$ & $(0.015)$ & $(0.012)$ & $(0.031)$ \\
\hline \multirow[t]{2}{*}{ First of the month: $8-14$ days before } & $0.042^{* *}$ & $0.027^{*}$ & -0.004 & $0.036^{* *}$ & 0.019 & 0.042 \\
\hline & $(0.019)$ & $(0.015)$ & $(0.037)$ & $(0.017)$ & $(0.013)$ & $(0.033)$ \\
\hline \multirow[t]{2}{*}{ First of the month: 0-6 days after } & -0.021 & -0.014 & 0.012 & 0.006 & $0.026^{* *}$ & 0.035 \\
\hline & $(0.018)$ & $(0.013)$ & $(0.032)$ & $(0.016)$ & $(0.012)$ & $(0.029)$ \\
\hline \multirow[t]{2}{*}{ First of the month: $7-13$ days after } & 0.007 & 0.017 & 0.002 & $0.052^{* * *}$ & $0.046^{* * *}$ & 0.049 \\
\hline & $(0.021)$ & $(0.016)$ & $(0.039)$ & $(0.019)$ & $(0.014)$ & $(0.037)$ \\
\hline \multirow[t]{2}{*}{ First of the month: other days } & $0.070^{* *}$ & 0.014 & $0.104^{*}$ & 0.040 & 0.010 & $0.100^{*}$ \\
\hline & $(0.029)$ & $(0.022)$ & $(0.059)$ & $(0.025)$ & $(0.020)$ & $(0.053)$ \\
\hline Day of the week & yes & yes & yes & yes & yes & yes \\
\hline Day of the survey & yes & yes & yes & yes & yes & yes \\
\hline Mean daily expenditures & 9.85 & 9.62 & 9.87 & 6.33 & 7.36 & 7.62 \\
\hline Fraction nonzero expenditures & 0.39 & 0.36 & 0.35 & 0.48 & 0.52 & 0.50 \\
\hline Adjusted R-squared & 0.15 & 0.12 & 0.10 & 0.34 & 0.30 & 0.30 \\
\hline
\end{tabular}

Each column is an OLS regression with household fixed effects. The dependent variable is transformed using the inverse hyperbolic sine, and trimmed at the 98th percentile. Total number of observations (households) is $81,731(6,018)$ for weekly paid households, $146,708(10,784)$ for biweekly, and 24,093 $(1,772)$ for monthly. The dummy variable ' $1-3$ days after housing payment' takes on value one for the first three days after a household pays rent or mortgage, and '4-6 days after housing payment' the three days following. All regressions contain controls for day of the week and day of the survey. The reference week for the weeks of the calendar month is the week before the first of the month. The dummy for 'First of the month: other days around' is not a full week, but contains in between 0 and 3 days, depending on the total number of days of the month. Robust standard errors (in parentheses) are clustered at the household level. ${ }^{*} / * / * * *$ correspond to $10 \% / 5 \% / 1 \%$ significance level. 
Table A2: Instant Consumption and Fresh Food After Housing Payment

\begin{tabular}{|c|c|c|c|c|c|c|}
\hline \multirow[b]{3}{*}{ Paycheck frequency } & \multicolumn{3}{|c|}{ A. Instant Consumption } & \multicolumn{3}{|c|}{ B. Fresh Food } \\
\hline & (1) & (2) & (3) & (4) & $(5)$ & (6) \\
\hline & Weekly & Biweekly & Monthly & Weekly & Biweekly & Monthly \\
\hline \multirow[t]{2}{*}{ Day of housing payment } & $0.209^{* * *}$ & $0.168^{* * *}$ & $0.205^{* * *}$ & $0.212^{* * *}$ & $0.167^{* * *}$ & $0.184^{* * *}$ \\
\hline & $(0.020)$ & $(0.015)$ & $(0.039)$ & $(0.016)$ & $(0.011)$ & $(0.030)$ \\
\hline \multirow[t]{2}{*}{ Housing payment: $1-3$ days after } & 0.017 & 0.015 & 0.030 & $0.021^{* *}$ & 0.010 & 0.007 \\
\hline & $(0.014)$ & $(0.011)$ & $(0.029)$ & $(0.009)$ & $(0.007)$ & $(0.017)$ \\
\hline \multirow{2}{*}{ Housing payment: 4-6 days after } & $-0.031^{* *}$ & -0.011 & $-0.074^{* *}$ & $-0.017^{*}$ & -0.006 & 0.010 \\
\hline & $(0.016)$ & $(0.012)$ & $(0.033)$ & $(0.010)$ & $(0.007)$ & $(0.019)$ \\
\hline \multirow[t]{2}{*}{ First of the month: $8-14$ days before } & 0.028 & 0.016 & 0.043 & $0.024^{* *}$ & 0.002 & -0.006 \\
\hline & $(0.017)$ & $(0.014)$ & $(0.034)$ & $(0.011)$ & $(0.008)$ & $(0.022)$ \\
\hline \multirow[t]{2}{*}{ First of the month: 0-6 days after } & -0.004 & $0.025^{* *}$ & 0.029 & -0.006 & -0.007 & -0.0001 \\
\hline & $(0.016)$ & $(0.012)$ & $(0.030)$ & $(0.010)$ & $(0.007)$ & $(0.018)$ \\
\hline \multirow{2}{*}{ First of the month: 7-13 days after } & $0.041^{* *}$ & $0.040^{* * *}$ & 0.058 & 0.005 & 0.010 & 0.014 \\
\hline & $(0.019)$ & $(0.015)$ & $(0.038)$ & $(0.012)$ & $(0.009)$ & $(0.022)$ \\
\hline \multirow{2}{*}{ First of the month: other days } & 0.039 & 0.014 & $0.131^{* *}$ & 0.021 & -0.0001 & $0.065^{*}$ \\
\hline & $(0.026)$ & $(0.021)$ & $(0.055)$ & $(0.017)$ & $(0.013)$ & $(0.034)$ \\
\hline Day of the week & yes & yes & yes & yes & yes & yes \\
\hline Day of the survey & yes & yes & yes & yes & yes & yes \\
\hline Mean daily expenditures & 7.05 & 8.37 & 8.84 & 1.42 & 1.37 & 1.50 \\
\hline Fraction nonzero expenditures & 0.49 & 0.53 & 0.52 & 0.22 & 0.21 & 0.21 \\
\hline Adjusted R-squared & 0.34 & 0.30 & 0.30 & 0.09 & 0.07 & 0.06 \\
\hline
\end{tabular}

Each column is an OLS regression with household fixed effects. The dependent variable is transformed using the inverse hyperbolic sine, and trimmed at the 98th percentile. Total number of observations (households) is $81,731(6,018)$ for weekly paid households, $146,708(10,784)$ for biweekly, and 24,093 $(1,772)$ for monthly. The dummy variable ' $1-3$ days after housing payment' takes on value one for the first three days after a household pays rent or mortgage, and '4-6 days after housing payment' the three days following. All regressions contain controls for day of the week and day of the survey. The reference week for the weeks of the calendar month is the week before the first of the month. The dummy for 'First of the month: other days around' is not a full week, but contains in between 0 and 3 days, depending on the total number of days of the month. Robust standard errors (in parentheses) are clustered at the household level. ${ }^{*} / * / * * *$ correspond to $10 \% / 5 \% / 1 \%$ significance level. 
Table A3: Heterogeneity: Food at Home After Payment of Rent or Mortgage

\begin{tabular}{|c|c|c|c|c|c|c|c|}
\hline & \multirow[b]{2}{*}{$\begin{array}{l}\text { Baseline } \\
\text { (1) }\end{array}$} & \multicolumn{2}{|c|}{ Budget Share Housing } & \multicolumn{2}{|c|}{ Housing Tenure } & \multicolumn{2}{|c|}{ Household Income } \\
\hline & & $\begin{array}{l}\text { Lowest } 25 \% \\
\text { (2) }\end{array}$ & $\begin{array}{c}\text { Highest } 25 \% \\
\text { (3) }\end{array}$ & $\begin{array}{l}\text { Rent } \\
(4)\end{array}$ & $\begin{array}{c}\text { Own Home } \\
(5)\end{array}$ & $\begin{array}{l}\text { Lowest } 20 \% \\
\text { (6) }\end{array}$ & $\begin{array}{c}\text { Highest } 20 \% \\
(7)\end{array}$ \\
\hline Day of housing payment & $\begin{array}{l}0.413^{* * *} \\
(0.025)\end{array}$ & $\begin{array}{l}0.469^{* * *} \\
(0.054)\end{array}$ & $\begin{array}{l}0.403^{* * *} \\
(0.047)\end{array}$ & $\begin{array}{l}0.451^{* * *} \\
(0.034)\end{array}$ & $\begin{array}{l}0.355^{* * *} \\
(0.038)\end{array}$ & $\begin{array}{l}0.432^{* * *} \\
(0.044)\end{array}$ & $\begin{array}{l}0.371^{* * *} \\
(0.090)\end{array}$ \\
\hline Housing payment: $1-3$ days after & $\begin{array}{c}0.027^{*} \\
(0.015)\end{array}$ & $\begin{array}{c}0.005 \\
(0.032)\end{array}$ & $\begin{array}{c}0.045 \\
(0.028)\end{array}$ & $\begin{array}{c}0.043^{* *} \\
(0.020)\end{array}$ & $\begin{array}{c}0.018 \\
(0.023)\end{array}$ & $\begin{array}{c}0.030 \\
(0.026)\end{array}$ & $\begin{array}{c}-0.014 \\
(0.052)\end{array}$ \\
\hline Housing payment: $4-6$ days after & $\begin{array}{c}-0.037^{* *} \\
(0.017)\end{array}$ & $\begin{array}{c}-0.025 \\
(0.036)\end{array}$ & $\begin{array}{c}-0.038 \\
(0.030)\end{array}$ & $\begin{array}{c}-0.045^{* *} \\
(0.021)\end{array}$ & $\begin{array}{c}-0.032 \\
(0.026)\end{array}$ & $\begin{array}{c}-0.024 \\
(0.027)\end{array}$ & $\begin{array}{c}-0.095 \\
(0.060)\end{array}$ \\
\hline Biweekly pay $\times$ Day of housing payment & $\begin{array}{c}-0.086^{* * *} \\
(0.032)\end{array}$ & $\begin{array}{c}-0.159^{* *} \\
(0.066)\end{array}$ & $\begin{array}{c}-0.074 \\
(0.061)\end{array}$ & $\begin{array}{c}-0.087^{* *} \\
(0.044)\end{array}$ & $\begin{array}{c}-0.069 \\
(0.046)\end{array}$ & $\begin{array}{c}-0.031 \\
(0.061)\end{array}$ & $\begin{array}{c}-0.112 \\
(0.101)\end{array}$ \\
\hline Biweekly pay $\times 1-3$ days after housing payment & $\begin{array}{c}0.0001 \\
(0.019)\end{array}$ & $\begin{array}{c}0.055 \\
(0.040)\end{array}$ & $\begin{array}{c}-0.009 \\
(0.036)\end{array}$ & $\begin{array}{c}-0.005 \\
(0.026)\end{array}$ & $\begin{array}{c}0.006 \\
(0.028)\end{array}$ & $\begin{array}{c}0.010 \\
(0.035)\end{array}$ & $\begin{array}{c}0.058 \\
(0.059)\end{array}$ \\
\hline Biweekly pay $\times 4-6$ days after housing payment & $\begin{array}{c}0.027 \\
(0.021)\end{array}$ & $\begin{array}{c}0.048 \\
(0.043)\end{array}$ & $\begin{array}{c}0.023 \\
(0.038)\end{array}$ & $\begin{array}{c}0.026 \\
(0.027)\end{array}$ & $\begin{array}{c}0.028 \\
(0.031)\end{array}$ & $\begin{array}{c}0.029 \\
(0.037)\end{array}$ & $\begin{array}{r}0.113^{*} \\
(0.067)\end{array}$ \\
\hline Monthly pay $\times$ Day of housing payment & $\begin{array}{c}-0.132^{* *} \\
(0.054)\end{array}$ & $\begin{array}{l}-0.311^{* * *} \\
(0.114)\end{array}$ & $\begin{array}{r}-0.174^{*} \\
(0.101)\end{array}$ & $\begin{array}{c}-0.078 \\
(0.078)\end{array}$ & $\begin{array}{c}-0.121 \\
(0.075)\end{array}$ & $\begin{array}{l}-0.125 \\
(0.114)\end{array}$ & $\begin{array}{c}-0.158 \\
(0.135)\end{array}$ \\
\hline Monthly pay $\times 1-3$ days after housing payment & $\begin{array}{c}-0.032 \\
(0.031)\end{array}$ & $\begin{array}{c}0.060 \\
(0.069)\end{array}$ & $\begin{array}{c}-0.087 \\
(0.058)\end{array}$ & $\begin{array}{l}0.001 \\
(0.046)\end{array}$ & $\begin{array}{c}-0.040 \\
(0.043)\end{array}$ & $\begin{array}{c}-0.052 \\
(0.058)\end{array}$ & $\begin{array}{c}-0.025 \\
(0.078)\end{array}$ \\
\hline Monthly pay $\times 4-6$ days after housing payment & $\begin{array}{l}0.036 \\
(0.035)\end{array}$ & $\begin{array}{c}0.072 \\
(0.076)\end{array}$ & $\begin{array}{c}0.002 \\
(0.068)\end{array}$ & $\begin{array}{c}0.071 \\
(0.051)\end{array}$ & $\begin{array}{c}0.023 \\
(0.050)\end{array}$ & $\begin{array}{c}-0.026 \\
(0.069)\end{array}$ & $\begin{array}{c}0.071 \\
(0.090)\end{array}$ \\
\hline Day of the week & yes & yes & yes & yes & yes & yes & yes \\
\hline Day of the survey & yes & yes & yes & yes & yes & yes & yes \\
\hline Week of the calendar month & yes & yes & yes & yes & yes & yes & yes \\
\hline Number of observations & 252,531 & 62,824 & 63,222 & 115,502 & 137,029 & 54,762 & 44,748 \\
\hline Number of households & 18,574 & 4,608 & 4,662 & 8,496 & 10,078 & 4,033 & 3,312 \\
\hline Mean daily expenditures & 9.72 & 10.99 & 8.71 & 7.59 & 11.60 & 6.56 & 14.37 \\
\hline Fraction nonzero expenditures & 0.37 & 0.39 & 0.35 & 0.35 & 0.39 & 0.33 & 0.41 \\
\hline Adjusted R-squared & 0.13 & 0.11 & 0.15 & 0.16 & 0.10 & 0.17 & 0.08 \\
\hline
\end{tabular}

Table A4: Heterogeneity: Food Away from Home After Payment of Rent or Mortgage

\begin{tabular}{|c|c|c|c|c|c|c|c|}
\hline & \multirow[b]{2}{*}{$\begin{array}{l}\text { Baseline } \\
\text { (1) }\end{array}$} & \multicolumn{2}{|c|}{ Budget Share Housing } & \multicolumn{2}{|c|}{ Housing Tenure } & \multicolumn{2}{|c|}{ Household Income } \\
\hline & & $\begin{array}{l}\text { Lowest } 25 \% \\
\quad(2)\end{array}$ & $\begin{array}{c}\text { Highest } 25 \% \\
\text { (3) }\end{array}$ & $\begin{array}{l}\text { Rent } \\
(4)\end{array}$ & $\begin{array}{c}\text { Own Home } \\
(5)\end{array}$ & $\begin{array}{l}\text { Lowest } 20 \% \\
\quad(6)\end{array}$ & $\begin{array}{l}\text { Highest } 20 \% \\
(7)\end{array}$ \\
\hline Day of housing payment & $\begin{array}{l}0.178^{* * *} \\
(0.019)\end{array}$ & $\begin{array}{l}0.182^{* * *} \\
(0.040)\end{array}$ & $\begin{array}{l}0.172^{* * *} \\
(0.034)\end{array}$ & $\begin{array}{l}0.204^{* * *} \\
(0.026)\end{array}$ & $\begin{array}{l}0.147^{* * *} \\
(0.029)\end{array}$ & $\begin{array}{l}0.229^{* * *} \\
(0.032)\end{array}$ & $\begin{array}{c}0.137^{*} \\
(0.073)\end{array}$ \\
\hline Housing payment: $1-3$ days after & $\begin{array}{c}0.013 \\
(0.013)\end{array}$ & $\begin{array}{c}-0.029 \\
(0.028)\end{array}$ & $\begin{array}{c}0.032 \\
(0.024)\end{array}$ & $\begin{array}{c}0.029 \\
(0.018)\end{array}$ & $\begin{array}{c}0.006 \\
(0.020)\end{array}$ & $\begin{array}{l}0.046^{* *} \\
(0.022)\end{array}$ & $\begin{array}{l}0.015 \\
(0.052)\end{array}$ \\
\hline Housing payment: $4-6$ days after & $\begin{array}{c}-0.030^{* *} \\
(0.015)\end{array}$ & $\begin{array}{r}-0.056^{*} \\
(0.031)\end{array}$ & $\begin{array}{c}0.004 \\
(0.026)\end{array}$ & $\begin{array}{c}-0.025 \\
(0.020)\end{array}$ & $\begin{array}{c}-0.032 \\
(0.022)\end{array}$ & $\begin{array}{c}0.008 \\
(0.023)\end{array}$ & $\begin{array}{c}-0.069 \\
(0.056)\end{array}$ \\
\hline Biweekly pay $\times$ Day of housing payment & $\begin{array}{r}-0.039 \\
(0.024)\end{array}$ & $\begin{array}{c}-0.051 \\
(0.049)\end{array}$ & $\begin{array}{c}-0.036 \\
(0.044)\end{array}$ & $\begin{array}{c}-0.026 \\
(0.033)\end{array}$ & $\begin{array}{c}-0.041 \\
(0.035)\end{array}$ & $\begin{array}{c}-0.089^{* *} \\
(0.044)\end{array}$ & $\begin{array}{c}-0.040 \\
(0.081)\end{array}$ \\
\hline Biweekly pay $\times 1-3$ days after housing payment & $\begin{array}{l}0.009 \\
(0.017)\end{array}$ & $\begin{array}{l}0.039 \\
(0.035)\end{array}$ & $\begin{array}{c}-0.013 \\
(0.031)\end{array}$ & $\begin{array}{l}0.005 \\
(0.023)\end{array}$ & $\begin{array}{c}0.007 \\
(0.024)\end{array}$ & $\begin{array}{c}-0.029 \\
(0.030)\end{array}$ & $\begin{array}{c}-0.002 \\
(0.057)\end{array}$ \\
\hline Biweekly pay $\times 4-6$ days after housing payment & $\begin{array}{c}0.018 \\
(0.018)\end{array}$ & $\begin{array}{c}0.041 \\
(0.039)\end{array}$ & $\begin{array}{c}-0.021 \\
(0.034)\end{array}$ & $\begin{array}{c}0.023 \\
(0.025)\end{array}$ & $\begin{array}{c}0.016 \\
(0.027)\end{array}$ & $\begin{array}{c}-0.048 \\
(0.032)\end{array}$ & $\begin{array}{l}0.029 \\
(0.062)\end{array}$ \\
\hline Monthly pay $\times$ Day of housing payment & $\begin{array}{c}-0.044 \\
(0.041)\end{array}$ & $\begin{array}{c}-0.050 \\
(0.092)\end{array}$ & $\begin{array}{c}-0.057 \\
(0.076)\end{array}$ & $\begin{array}{c}-0.088 \\
(0.059)\end{array}$ & $\begin{array}{c}-0.016 \\
(0.057)\end{array}$ & $\begin{array}{c}-0.020 \\
(0.085)\end{array}$ & $\begin{array}{c}-0.101 \\
(0.104)\end{array}$ \\
\hline Monthly pay $\times 1-3$ days after housing payment & $\begin{array}{c}0.006 \\
(0.028)\end{array}$ & $\begin{array}{r}0.102^{*} \\
(0.061)\end{array}$ & $\begin{array}{c}0.001 \\
(0.053)\end{array}$ & $\begin{array}{l}0.017 \\
(0.042)\end{array}$ & $\begin{array}{c}-0.007 \\
(0.039)\end{array}$ & $\begin{array}{c}-0.026 \\
(0.053)\end{array}$ & $\begin{array}{c}0.018 \\
(0.075)\end{array}$ \\
\hline Monthly pay $\times 4-6$ days after housing payment & $\begin{array}{c}-0.028 \\
(0.033) \\
\end{array}$ & $\begin{array}{c}0.073 \\
(0.073) \\
\end{array}$ & $\begin{array}{c}-0.039 \\
(0.058) \\
\end{array}$ & $\begin{array}{c}0.005 \\
(0.047) \\
\end{array}$ & $\begin{array}{c}-0.056 \\
(0.046) \\
\end{array}$ & $\begin{array}{c}0.004 \\
(0.063) \\
\end{array}$ & $\begin{array}{c}-0.048 \\
(0.084) \\
\end{array}$ \\
\hline Day of the week & yes & yes & yes & yes & yes & yes & yes \\
\hline Day of the survey & yes & yes & yes & yes & yes & yes & yes \\
\hline Week of the calendar month & yes & yes & yes & yes & yes & yes & yes \\
\hline Number of observations & 252,531 & 62,824 & 63,222 & 115,502 & 137,029 & 54,762 & 44,748 \\
\hline Number of households & 18,574 & 4,608 & 4,662 & 8,496 & 10,078 & 4,033 & 3,312 \\
\hline Mean daily expenditures & 7.05 & 8.34 & 5.45 & 5.71 & 8.21 & 3.71 & 12.24 \\
\hline Fraction nonzero expenditures & 0.50 & 0.54 & 0.44 & 0.46 & 0.54 & 0.38 & 0.62 \\
\hline Adjusted R-squared & 0.32 & 0.30 & 0.33 & 0.33 & 0.29 & 0.31 & 0.28 \\
\hline
\end{tabular}


Table A5: Heterogeneity: Instant Consumption After Payment of Rent or Mortgage

\begin{tabular}{|c|c|c|c|c|c|c|c|}
\hline & \multirow[b]{2}{*}{$\begin{array}{l}\text { Baseline } \\
\text { (1) }\end{array}$} & \multicolumn{2}{|c|}{ Budget Share Housing } & \multicolumn{2}{|c|}{ Housing Tenure } & \multicolumn{2}{|c|}{ Household Income } \\
\hline & & $\begin{array}{l}\text { Lowest } 25 \% \\
\text { (2) }\end{array}$ & $\begin{array}{l}\text { Highest } 25 \% \\
\text { (3) }\end{array}$ & $\begin{array}{l}\text { Rent } \\
(4)\end{array}$ & $\begin{array}{c}\text { Own Home } \\
(5)\end{array}$ & $\begin{array}{l}\text { Lowest } 20 \% \\
\text { (6) }\end{array}$ & $\begin{array}{c}\text { Highest } 20 \% \\
(7)\end{array}$ \\
\hline Day of housing payment & $\begin{array}{l}0.212^{* * *} \\
(0.020)\end{array}$ & $\begin{array}{l}0.208^{* * *} \\
(0.041)\end{array}$ & $\begin{array}{l}0.201^{* * *} \\
(0.036)\end{array}$ & $\begin{array}{l}0.233^{* * *} \\
(0.026)\end{array}$ & $\begin{array}{l}0.182^{* * *} \\
(0.030)\end{array}$ & $\begin{array}{l}0.261^{* * *} \\
(0.033)\end{array}$ & $\begin{array}{l}0.238^{* * *} \\
(0.076)\end{array}$ \\
\hline Housing payment: 1-3 days after & $\begin{array}{c}0.011 \\
(0.014)\end{array}$ & $\begin{array}{c}-0.040 \\
(0.029)\end{array}$ & $\begin{array}{c}0.024 \\
(0.024)\end{array}$ & $\begin{array}{c}0.024 \\
(0.019)\end{array}$ & $\begin{array}{c}0.005 \\
(0.020)\end{array}$ & $\begin{array}{c}0.041^{*} \\
(0.022)\end{array}$ & $\begin{array}{c}0.022 \\
(0.053)\end{array}$ \\
\hline Housing payment: $4-6$ days after & $\begin{array}{c}-0.035^{* *} \\
(0.015)\end{array}$ & $\begin{array}{r}-0.055^{*} \\
(0.032)\end{array}$ & $\begin{array}{c}-0.005 \\
(0.027)\end{array}$ & $\begin{array}{c}-0.033 \\
(0.020)\end{array}$ & $\begin{array}{r}-0.040^{*} \\
(0.023)\end{array}$ & $\begin{array}{c}-0.006 \\
(0.024)\end{array}$ & $\begin{array}{c}-0.073 \\
(0.058)\end{array}$ \\
\hline Biweekly pay $\times$ Day of housing payment & $\begin{array}{c}-0.038 \\
(0.025)\end{array}$ & $\begin{array}{c}-0.033 \\
(0.051)\end{array}$ & $\begin{array}{c}-0.031 \\
(0.046)\end{array}$ & $\begin{array}{c}-0.009 \\
(0.035)\end{array}$ & $\begin{array}{c}-0.039 \\
(0.036)\end{array}$ & $\begin{array}{c}-0.107^{* *} \\
(0.046)\end{array}$ & $\begin{array}{c}-0.109 \\
(0.084)\end{array}$ \\
\hline Biweekly pay $\times 1-3$ days after housing payment & $\begin{array}{c}0.005 \\
(0.017)\end{array}$ & $\begin{array}{c}0.045 \\
(0.036)\end{array}$ & $\begin{array}{c}-0.008 \\
(0.032)\end{array}$ & $\begin{array}{c}0.006 \\
(0.024)\end{array}$ & $\begin{array}{c}0.005 \\
(0.025)\end{array}$ & $\begin{array}{c}-0.030 \\
(0.031)\end{array}$ & $\begin{array}{c}-0.008 \\
(0.059)\end{array}$ \\
\hline Biweekly pay $\times 4-6$ days after housing payment & $\begin{array}{c}0.023 \\
(0.019)\end{array}$ & $\begin{array}{c}0.042 \\
(0.040)\end{array}$ & $\begin{array}{c}-0.013 \\
(0.035)\end{array}$ & $\begin{array}{c}0.032 \\
(0.026)\end{array}$ & $\begin{array}{c}0.024 \\
(0.028)\end{array}$ & $\begin{array}{c}-0.025 \\
(0.033)\end{array}$ & $\begin{array}{c}0.042 \\
(0.065)\end{array}$ \\
\hline Monthly pay $\times$ Day of housing payment & $\begin{array}{c}-0.012 \\
(0.043)\end{array}$ & $\begin{array}{l}0.017 \\
(0.095)\end{array}$ & $\begin{array}{c}0.013 \\
(0.079)\end{array}$ & $\begin{array}{c}-0.030 \\
(0.061)\end{array}$ & $\begin{array}{c}0.023 \\
(0.060)\end{array}$ & $\begin{array}{c}-0.032 \\
(0.087)\end{array}$ & $\begin{array}{c}-0.093 \\
(0.111)\end{array}$ \\
\hline Monthly pay $\times 1-3$ days after housing payment & $\begin{array}{c}0.028 \\
(0.030)\end{array}$ & $\begin{array}{l}0.116^{*} \\
(0.063)\end{array}$ & $\begin{array}{c}0.030 \\
(0.055)\end{array}$ & $\begin{array}{c}0.049 \\
(0.043)\end{array}$ & $\begin{array}{c}0.011 \\
(0.041)\end{array}$ & $\begin{array}{c}-0.007 \\
(0.055)\end{array}$ & $\begin{array}{c}0.037 \\
(0.077)\end{array}$ \\
\hline Monthly pay $\times 4-6$ days after housing payment & $\begin{array}{c}-0.019 \\
(0.034)\end{array}$ & $\begin{array}{l}0.120 \\
(0.076)\end{array}$ & $\begin{array}{c}-0.029 \\
(0.059)\end{array}$ & $\begin{array}{c}0.019 \\
(0.048)\end{array}$ & $\begin{array}{c}-0.043 \\
(0.048)\end{array}$ & $\begin{array}{c}0.049 \\
(0.063)\end{array}$ & $\begin{array}{c}-0.022 \\
(0.088)\end{array}$ \\
\hline Day of the week & yes & yes & yes & yes & yes & yes & yes \\
\hline Day of the survey & yes & yes & yes & yes & yes & yes & yes \\
\hline Week of the calendar month & yes & yes & yes & yes & yes & yes & yes \\
\hline Number of observations & 252,531 & 62,824 & 63,222 & 115,502 & 137,029 & 54,762 & 44,748 \\
\hline Number of households & 18,574 & 4,608 & 4,662 & 8,496 & 10,078 & 4,033 & 3,312 \\
\hline Mean daily expenditures & 7.98 & 9.45 & 6.17 & 6.35 & 9.41 & 4.11 & 14.30 \\
\hline Fraction nonzero expenditures & 0.52 & 0.56 & 0.45 & 0.47 & 0.56 & 0.39 & 0.64 \\
\hline Adjusted R-squared & 0.31 & 0.30 & 0.32 & 0.33 & 0.29 & 0.31 & 0.27 \\
\hline
\end{tabular}

Table A6: Heterogeneity: Fresh Food After Payment of Rent or Mortgage

\begin{tabular}{|c|c|c|c|c|c|c|c|}
\hline & \multirow[b]{2}{*}{$\begin{array}{l}\text { Baseline } \\
\text { (1) }\end{array}$} & \multicolumn{2}{|c|}{ Budget Share Housing } & \multicolumn{2}{|c|}{ Housing Tenure } & \multicolumn{2}{|c|}{ Household Income } \\
\hline & & $\begin{array}{l}\text { Lowest } 25 \% \\
\quad(2)\end{array}$ & $\begin{array}{c}\text { Highest } 25 \% \\
\text { (3) }\end{array}$ & $\begin{array}{l}\text { Rent } \\
(4)\end{array}$ & $\begin{array}{c}\text { Own Home } \\
(5)\end{array}$ & $\begin{array}{l}\text { Lowest } 20 \% \\
\quad(6)\end{array}$ & $\begin{array}{l}\text { Highest } 20 \% \\
(7)\end{array}$ \\
\hline Day of housing payment & $\begin{array}{l}0.218^{* * *} \\
(0.015)\end{array}$ & $\begin{array}{l}0.218^{* * *} \\
(0.032)\end{array}$ & $\begin{array}{l}0.244^{* * *} \\
(0.029)\end{array}$ & $\begin{array}{l}0.236^{* * *} \\
(0.020)\end{array}$ & $\begin{array}{l}0.186^{* * *} \\
(0.024)\end{array}$ & $\begin{array}{l}0.230^{* * *} \\
(0.026)\end{array}$ & $\begin{array}{l}0.191^{* * *} \\
(0.056)\end{array}$ \\
\hline Housing payment: $1-3$ days after & $\begin{aligned} 0.015^{*} \\
(0.009)\end{aligned}$ & $\begin{array}{l}0.037^{* *} \\
(0.018)\end{array}$ & $\begin{array}{c}0.011 \\
(0.016)\end{array}$ & $\begin{array}{r}0.020^{*} \\
(0.011)\end{array}$ & $\begin{array}{c}0.012 \\
(0.013)\end{array}$ & $\begin{array}{c}0.009 \\
(0.014)\end{array}$ & $\begin{array}{l}0.016 \\
(0.031)\end{array}$ \\
\hline Housing payment: $4-6$ days after & $\begin{array}{c}-0.022^{* *} \\
(0.009)\end{array}$ & $\begin{array}{c}-0.025 \\
(0.020)\end{array}$ & $\begin{array}{r}-0.016 \\
(0.017)\end{array}$ & $\begin{array}{c}-0.013 \\
(0.012)\end{array}$ & $\begin{array}{r}-0.026^{*} \\
(0.014)\end{array}$ & $\begin{array}{c}-0.007 \\
(0.016)\end{array}$ & $\begin{array}{c}-0.044 \\
(0.035)\end{array}$ \\
\hline Biweekly pay $\times$ Day of housing payment & $\begin{array}{l}-0.052^{* * *} \\
(0.019)\end{array}$ & $\begin{array}{r}-0.068^{*} \\
(0.039)\end{array}$ & $\begin{array}{c}-0.058 \\
(0.037)\end{array}$ & $\begin{array}{c}-0.058^{* *} \\
(0.026)\end{array}$ & $\begin{array}{l}-0.027 \\
(0.028)\end{array}$ & $\begin{array}{c}-0.047 \\
(0.035)\end{array}$ & $\begin{array}{c}-0.046 \\
(0.062)\end{array}$ \\
\hline Biweekly pay $\times 1-3$ days after housing payment & $\begin{array}{c}-0.005 \\
(0.011)\end{array}$ & $\begin{array}{c}-0.022 \\
(0.022)\end{array}$ & $\begin{array}{c}-0.001 \\
(0.020)\end{array}$ & $\begin{array}{r}-0.007 \\
(0.014)\end{array}$ & $\begin{array}{c}-0.002 \\
(0.016)\end{array}$ & $\begin{array}{r}-0.003 \\
(0.019)\end{array}$ & $\begin{array}{l}0.018 \\
(0.035)\end{array}$ \\
\hline Biweekly pay $\times 4-6$ days after housing payment & $\begin{array}{c}0.018 \\
(0.012)\end{array}$ & $\begin{array}{c}0.029 \\
(0.024)\end{array}$ & $\begin{array}{c}0.008 \\
(0.022)\end{array}$ & $\begin{array}{c}0.006 \\
(0.015)\end{array}$ & $\begin{array}{r}0.030^{*} \\
(0.017)\end{array}$ & $\begin{array}{c}0.008 \\
(0.021)\end{array}$ & $\begin{array}{c}0.038 \\
(0.039)\end{array}$ \\
\hline Monthly pay $\times$ Day of housing payment & $\begin{array}{c}-0.034 \\
(0.033)\end{array}$ & $\begin{array}{r}-0.124^{*} \\
(0.067)\end{array}$ & $\begin{array}{c}-0.039 \\
(0.064)\end{array}$ & $\begin{array}{c}-0.054 \\
(0.045)\end{array}$ & $\begin{array}{c}-0.027 \\
(0.046)\end{array}$ & $\begin{array}{c}-0.029 \\
(0.064)\end{array}$ & $\begin{array}{c}0.012 \\
(0.084)\end{array}$ \\
\hline Monthly pay $\times 1-3$ days after housing payment & $\begin{array}{c}-0.004 \\
(0.018)\end{array}$ & $\begin{array}{l}0.015 \\
(0.040)\end{array}$ & $\begin{array}{c}0.022 \\
(0.034)\end{array}$ & $\begin{array}{c}-0.011 \\
(0.025)\end{array}$ & $\begin{array}{l}0.006 \\
(0.025)\end{array}$ & $\begin{array}{c}-0.026 \\
(0.030)\end{array}$ & $\begin{array}{c}-0.011 \\
(0.047)\end{array}$ \\
\hline Monthly pay $\times 4-6$ days after housing payment & $\begin{array}{l}0.045^{* *} \\
(0.020) \\
\end{array}$ & $\begin{array}{l}0.078^{*} \\
(0.044)\end{array}$ & $\begin{array}{c}0.021 \\
(0.038) \\
\end{array}$ & $\begin{array}{c}0.029 \\
(0.028) \\
\end{array}$ & $\begin{array}{c}0.046 \\
(0.028) \\
\end{array}$ & $\begin{array}{c}0.021 \\
(0.039) \\
\end{array}$ & $\begin{array}{c}0.070 \\
(0.053) \\
\end{array}$ \\
\hline Day of the week & yes & yes & yes & yes & yes & yes & yes \\
\hline Day of the survey & yes & yes & yes & yes & yes & yes & yes \\
\hline Week of the calendar month & yes & yes & yes & yes & yes & yes & yes \\
\hline Number of observations & 252,531 & 62,824 & 63,222 & 115,502 & 137,029 & 54,762 & 44,748 \\
\hline Number of households & 18,574 & 4,608 & 4,662 & 8,496 & 10,078 & 4,033 & 3,312 \\
\hline Mean daily expenditures & 1.40 & 1.50 & 1.36 & 1.12 & 1.64 & 0.98 & 2.06 \\
\hline Fraction nonzero expenditures & 0.21 & 0.22 & 0.21 & 0.19 & 0.23 & 0.18 & 0.25 \\
\hline Adjusted R-squared & 0.08 & 0.07 & 0.10 & 0.10 & 0.06 & 0.10 & 0.04 \\
\hline
\end{tabular}


Table A7: Robustness: Food at Home After Payment of Rent or Mortgage

\begin{tabular}{|c|c|c|c|c|c|}
\hline & \multicolumn{2}{|c|}{ Earner Composition } & \multicolumn{3}{|c|}{ Day of the Month of Housing Payment } \\
\hline & $\begin{array}{l}\text { Dual } \\
(1)\end{array}$ & $\begin{array}{c}\text { Single } \\
(2)\end{array}$ & $\begin{array}{l}\text { First of the Month } \\
\text { (3) }\end{array}$ & $\begin{array}{l}\text { Around the First } \\
\text { (4) }\end{array}$ & $\begin{array}{l}\text { Other Days } \\
\text { (5) }\end{array}$ \\
\hline \multirow[t]{2}{*}{ Day of housing payment } & $0.443^{* * *}$ & $0.399^{* * *}$ & 0.012 & $0.424^{* * *}$ & $0.497^{* * *}$ \\
\hline & $(0.050)$ & $(0.030)$ & $(0.065)$ & $(0.041)$ & $(0.037)$ \\
\hline \multirow[t]{2}{*}{ Housing payment: $1-3$ days after } & 0.016 & $0.032^{*}$ & -0.0001 & 0.008 & 0.034 \\
\hline & $(0.030)$ & $(0.017)$ & $(0.042)$ & $(0.025)$ & $(0.021)$ \\
\hline \multirow[t]{2}{*}{ Housing payment: $4-6$ days after } & -0.039 & $-0.044^{* *}$ & $-0.110^{* *}$ & -0.029 & -0.035 \\
\hline & $(0.032)$ & $(0.019)$ & $(0.045)$ & $(0.028)$ & $(0.023)$ \\
\hline \multirow{2}{*}{ Biweekly pay $\times$ Day of housing payment } & $-0.169^{* * *}$ & -0.053 & $0.141^{*}$ & $-0.100^{* *}$ & $-0.128^{* * *}$ \\
\hline & $(0.061)$ & $(0.037)$ & $(0.082)$ & $(0.051)$ & $(0.046)$ \\
\hline \multirow{2}{*}{ Biweekly pay $\times 1-3$ days after housing payment } & 0.002 & 0.003 & 0.037 & -0.003 & -0.001 \\
\hline & $(0.036)$ & $(0.022)$ & $(0.052)$ & $(0.030)$ & $(0.027)$ \\
\hline \multirow[t]{2}{*}{ Biweekly pay $\times 4-6$ days after housing payment } & 0.030 & 0.032 & 0.030 & 0.040 & 0.021 \\
\hline & $(0.039)$ & $(0.024)$ & $(0.056)$ & $(0.034)$ & $(0.029)$ \\
\hline \multirow[t]{2}{*}{ Monthly pay $\times$ Day of housing payment } & $-0.308^{* * *}$ & -0.052 & 0.112 & $-0.199^{* *}$ & -0.134 \\
\hline & $(0.109)$ & $(0.062)$ & $(0.126)$ & $(0.083)$ & $(0.085)$ \\
\hline \multirow{2}{*}{ Monthly pay $\times 1-3$ days after housing payment } & -0.006 & -0.026 & -0.028 & -0.036 & -0.029 \\
\hline & $(0.064)$ & $(0.036)$ & $(0.080)$ & $(0.048)$ & $(0.048)$ \\
\hline \multirow{2}{*}{ Monthly pay $\times 4-6$ days after housing payment } & 0.010 & 0.050 & 0.095 & -0.009 & 0.056 \\
\hline & $(0.071)$ & $(0.040)$ & $(0.090)$ & $(0.054)$ & $(0.055)$ \\
\hline Day of the week & yes & yes & yes & yes & yes \\
\hline Day of the survey & yes & yes & yes & yes & yes \\
\hline Week of the calendar month & yes & yes & no & no & no \\
\hline Number of observations & 80311 & 172221 & 32537 & 97049 & 122945 \\
\hline Number of households & 5911 & 12663 & 2390 & 7176 & 9008 \\
\hline Mean daily expenditures & 12.51 & 8.46 & 8.69 & 9.42 & 10.22 \\
\hline Fraction nonzero expenditures & 0.41 & 0.35 & 0.35 & 0.37 & 0.38 \\
\hline Adjusted R-squared & 0.10 & 0.14 & 0.12 & 0.13 & 0.13 \\
\hline
\end{tabular}


Table A8: Robustness: Food Away from Home After Payment of Rent or Mortgage

\begin{tabular}{|c|c|c|c|c|c|}
\hline & \multicolumn{2}{|c|}{ Earner Composition } & \multicolumn{3}{|c|}{ Day of the Month of Housing Payment } \\
\hline & $\begin{array}{l}\text { Dual } \\
(1)\end{array}$ & $\begin{array}{c}\text { Single } \\
(2)\end{array}$ & $\begin{array}{l}\text { First of the Month } \\
\text { (3) }\end{array}$ & $\begin{array}{l}\text { Around the First } \\
\text { (4) }\end{array}$ & $\begin{array}{c}\text { Other Days } \\
(5)\end{array}$ \\
\hline \multirow[t]{2}{*}{ Day of housing payment } & $0.134^{* * *}$ & $0.201^{* * *}$ & $0.120^{* *}$ & $0.162^{* * *}$ & $0.203^{* * *}$ \\
\hline & $(0.037)$ & $(0.022)$ & $(0.051)$ & $(0.031)$ & $(0.028)$ \\
\hline \multirow[t]{2}{*}{ Housing payment: $1-3$ days after } & 0.009 & 0.016 & -0.017 & -0.002 & 0.028 \\
\hline & $(0.026)$ & $(0.016)$ & $(0.037)$ & $(0.022)$ & $(0.019)$ \\
\hline \multirow[t]{2}{*}{ Housing payment: 4-6 days after } & -0.039 & -0.022 & $-0.083^{* *}$ & -0.024 & -0.019 \\
\hline & $(0.028)$ & $(0.017)$ & $(0.040)$ & $(0.024)$ & $(0.021)$ \\
\hline \multirow[t]{2}{*}{ Biweekly pay $\times$ Day of housing payment } & 0.016 & $-0.070^{* *}$ & -0.041 & -0.023 & -0.051 \\
\hline & $(0.045)$ & $(0.028)$ & $(0.064)$ & $(0.039)$ & $(0.035)$ \\
\hline \multirow{2}{*}{ Biweekly pay $\times 1-3$ days after housing payment } & -0.033 & 0.025 & 0.036 & 0.018 & -0.004 \\
\hline & $(0.031)$ & $(0.020)$ & $(0.046)$ & $(0.027)$ & $(0.024)$ \\
\hline \multirow[t]{2}{*}{ Biweekly pay $\times 4-6$ days after housing payment } & -0.002 & 0.023 & 0.084 & 0.006 & 0.010 \\
\hline & $(0.034)$ & $(0.022)$ & $(0.051)$ & $(0.030)$ & $(0.026)$ \\
\hline \multirow[t]{2}{*}{ Monthly pay $\times$ Day of housing payment } & 0.047 & $-0.096^{* *}$ & -0.023 & -0.008 & -0.088 \\
\hline & $(0.080)$ & $(0.048)$ & $(0.095)$ & $(0.064)$ & $(0.065)$ \\
\hline \multirow[t]{2}{*}{ Monthly pay $\times 1-3$ days after housing payment } & -0.041 & 0.020 & 0.095 & 0.020 & -0.030 \\
\hline & $(0.056)$ & $(0.033)$ & $(0.073)$ & $(0.044)$ & $(0.043)$ \\
\hline \multirow{2}{*}{ Monthly pay $\times 4-6$ days after housing payment } & -0.002 & -0.038 & 0.076 & -0.009 & $-0.085^{*}$ \\
\hline & $(0.065)$ & $(0.038)$ & $(0.087)$ & $(0.050)$ & $(0.050)$ \\
\hline Day of the week & yes & yes & yes & yes & yes \\
\hline Day of the survey & yes & yes & yes & yes & yes \\
\hline Week of the calendar month & yes & yes & no & no & no \\
\hline Number of observations & 80311 & 172221 & 32537 & 97049 & 122945 \\
\hline Number of households & 5911 & 12663 & 2390 & 7176 & 9008 \\
\hline Mean daily expenditures & 8.88 & 6.21 & 6.48 & 6.81 & 7.38 \\
\hline Fraction nonzero expenditures & 0.56 & 0.48 & 0.48 & 0.50 & 0.51 \\
\hline Adjusted R-squared & 0.29 & 0.32 & 0.32 & 0.32 & 0.31 \\
\hline
\end{tabular}


Table A9: Robustness: Instant Consumption After Payment of Rent or Mortgage

\begin{tabular}{|c|c|c|c|c|c|}
\hline & \multicolumn{2}{|c|}{ Earner Composition } & \multicolumn{3}{|c|}{ Day of the Month of Housing Payment } \\
\hline & $\begin{array}{l}\text { Dual } \\
(1)\end{array}$ & $\begin{array}{c}\text { Single } \\
(2)\end{array}$ & $\begin{array}{l}\text { First of the Month } \\
\text { (3) }\end{array}$ & $\begin{array}{l}\text { Around the First } \\
\text { (4) }\end{array}$ & $\begin{array}{c}\text { Other Days } \\
(5)\end{array}$ \\
\hline \multirow[t]{2}{*}{ Day of housing payment } & $0.153^{* * *}$ & $0.226^{* * *}$ & $0.171^{* * *}$ & $0.182^{* * *}$ & $0.234^{* * *}$ \\
\hline & $(0.038)$ & $(0.023)$ & $(0.053)$ & $(0.032)$ & $(0.029)$ \\
\hline \multirow[t]{2}{*}{ Housing payment: $1-3$ days after } & 0.003 & 0.011 & -0.025 & -0.002 & 0.025 \\
\hline & $(0.027)$ & $(0.016)$ & $(0.038)$ & $(0.022)$ & $(0.019)$ \\
\hline \multirow[t]{2}{*}{ Housing payment: 4-6 days after } & $-0.049^{*}$ & -0.028 & $-0.091^{* *}$ & -0.030 & -0.024 \\
\hline & $(0.030)$ & $(0.018)$ & $(0.042)$ & $(0.025)$ & $(0.022)$ \\
\hline \multirow[t]{2}{*}{ Biweekly pay $\times$ Day of housing payment } & 0.025 & $-0.056^{*}$ & -0.046 & -0.029 & -0.038 \\
\hline & $(0.047)$ & $(0.029)$ & $(0.067)$ & $(0.040)$ & $(0.036)$ \\
\hline \multirow{2}{*}{ Biweekly pay $\times 1-3$ days after housing payment } & -0.031 & 0.028 & 0.051 & 0.009 & -0.001 \\
\hline & $(0.033)$ & $(0.020)$ & $(0.048)$ & $(0.028)$ & $(0.024)$ \\
\hline \multirow[t]{2}{*}{ Biweekly pay $\times 4-6$ days after housing payment } & 0.004 & $0.037^{*}$ & $0.103^{*}$ & 0.002 & 0.022 \\
\hline & $(0.036)$ & $(0.022)$ & $(0.053)$ & $(0.031)$ & $(0.027)$ \\
\hline \multirow[t]{2}{*}{ Monthly pay $\times$ Day of housing payment } & 0.120 & -0.053 & -0.024 & 0.032 & -0.028 \\
\hline & $(0.085)$ & $(0.050)$ & $(0.100)$ & $(0.068)$ & $(0.067)$ \\
\hline \multirow[t]{2}{*}{ Monthly pay $\times 1-3$ days after housing payment } & -0.038 & 0.055 & $0.127^{*}$ & 0.032 & -0.006 \\
\hline & $(0.058)$ & $(0.034)$ & $(0.074)$ & $(0.046)$ & $(0.046)$ \\
\hline \multirow{2}{*}{ Monthly pay $\times 4-6$ days after housing payment } & -0.010 & -0.035 & 0.113 & -0.019 & -0.062 \\
\hline & $(0.069)$ & $(0.039)$ & $(0.092)$ & $(0.051)$ & $(0.053)$ \\
\hline Day of the week & yes & yes & yes & yes & yes \\
\hline Day of the survey & yes & yes & yes & yes & yes \\
\hline Week of the calendar month & yes & yes & no & no & no \\
\hline Number of observations & 80311 & 172221 & 32537 & 97049 & 122945 \\
\hline Number of households & 5911 & 12663 & 2390 & 7176 & 9008 \\
\hline Mean daily expenditures & 10.23 & 6.96 & 7.27 & 7.71 & 8.39 \\
\hline Fraction nonzero expenditures & 0.57 & 0.49 & 0.50 & 0.51 & 0.53 \\
\hline Adjusted R-squared & 0.29 & 0.32 & 0.32 & 0.31 & 0.31 \\
\hline
\end{tabular}


Table A10: Robustness: Fresh Food After Payment of Rent or Mortgage

\begin{tabular}{|c|c|c|c|c|c|}
\hline & \multicolumn{2}{|c|}{ Earner Composition } & \multicolumn{3}{|c|}{ Day of the Month of Housing Payment } \\
\hline & $\begin{array}{l}\text { Dual } \\
(1)\end{array}$ & $\begin{array}{c}\text { Single } \\
(2)\end{array}$ & $\begin{array}{l}\text { First of the Month } \\
\text { (3) }\end{array}$ & $\begin{array}{l}\text { Around the First } \\
\text { (4) }\end{array}$ & $\begin{array}{c}\text { Other Days } \\
\text { (5) }\end{array}$ \\
\hline \multirow[t]{2}{*}{ Day of housing payment } & $0.236^{* * *}$ & $0.214^{* * *}$ & $0.065^{*}$ & $0.236^{* * *}$ & $0.237^{* * *}$ \\
\hline & $(0.031)$ & $(0.018)$ & $(0.039)$ & $(0.025)$ & $(0.023)$ \\
\hline \multirow[t]{2}{*}{ Housing payment: $1-3$ days after } & 0.018 & 0.014 & 0.020 & 0.013 & 0.015 \\
\hline & $(0.017)$ & $(0.010)$ & $(0.024)$ & $(0.013)$ & $(0.012)$ \\
\hline \multirow[t]{2}{*}{ Housing payment: $4-6$ days after } & -0.023 & $-0.021^{* *}$ & $-0.046^{*}$ & -0.011 & $-0.027^{* *}$ \\
\hline & $(0.019)$ & $(0.011)$ & $(0.026)$ & $(0.015)$ & $(0.013)$ \\
\hline \multirow[t]{2}{*}{ Biweekly pay $\times$ Day of housing payment } & $-0.086^{* *}$ & $-0.042^{*}$ & 0.010 & $-0.074^{* *}$ & $-0.046^{*}$ \\
\hline & $(0.037)$ & $(0.022)$ & $(0.048)$ & $(0.031)$ & $(0.028)$ \\
\hline \multirow{2}{*}{ Biweekly pay $\times 1-3$ days after housing payment } & -0.020 & -0.0001 & -0.012 & -0.007 & -0.003 \\
\hline & $(0.021)$ & $(0.012)$ & $(0.029)$ & $(0.017)$ & $(0.015)$ \\
\hline \multirow[t]{2}{*}{ Biweekly pay $\times 4-6$ days after housing payment } & 0.020 & 0.013 & 0.012 & 0.006 & 0.025 \\
\hline & $(0.023)$ & $(0.013)$ & $(0.032)$ & $(0.019)$ & $(0.016)$ \\
\hline \multirow[t]{2}{*}{ Monthly pay $\times$ Day of housing payment } & -0.086 & -0.032 & 0.087 & -0.073 & -0.038 \\
\hline & $(0.068)$ & $(0.036)$ & $(0.078)$ & $(0.050)$ & $(0.051)$ \\
\hline \multirow{2}{*}{ Monthly pay $\times 1-3$ days after housing payment } & 0.009 & -0.012 & -0.062 & -0.014 & 0.018 \\
\hline & $(0.038)$ & $(0.020)$ & $(0.045)$ & $(0.027)$ & $(0.028)$ \\
\hline \multirow[t]{2}{*}{ Monthly pay $\times$ 4- 6 days after housing payment } & 0.017 & $0.047^{* *}$ & 0.066 & 0.003 & $0.073^{* *}$ \\
\hline & $(0.040)$ & $(0.023)$ & $(0.051)$ & $(0.029)$ & $(0.033)$ \\
\hline Day of the week & yes & yes & yes & yes & yes \\
\hline Day of the survey & yes & yes & yes & yes & yes \\
\hline Week of the calendar month & yes & yes & no & no & no \\
\hline Number of observations & 80311 & 172220 & 32536 & 97049 & 122944 \\
\hline Number of households & 5911 & 12663 & 2390 & 7176 & 9008 \\
\hline Mean daily expenditures & 1.79 & 1.22 & 1.28 & 1.35 & 1.46 \\
\hline Fraction nonzero expenditures & 0.25 & 0.20 & 0.20 & 0.21 & 0.22 \\
\hline Adjusted R-squared & 0.05 & 0.09 & 0.07 & 0.08 & 0.08 \\
\hline
\end{tabular}




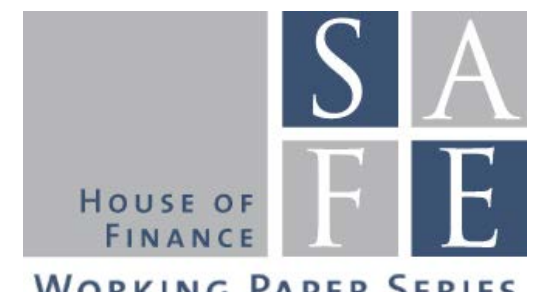

WORKINg PAPER SERIES

\section{Recent Issues}

No. 236 Aleksey Kolokolov, Giulia Livieri, Davide Pirino

No. 235 Christian Kubitza, Loriana Pelizzon, Mila Getmansky Sherman

No. 234 Alejandro Bernales, Nicolás Garrido, Satchit Sagade, Marcela Valenzuela, Christian Westheide

No. 233 Baptiste Massenot, Yuri Pettinicchi

No. 232 Jannic Alexander Cutura

No. 231 Benjamin Clapham, Peter Gomber, Jens Lausen, Sven Panz

No. 230 Yalin Gündüz, Giorgio Ottonello, Loriana Pelizzon, Michael Schneider, Marti G.

Subrahmanyam

No. 229 Daniel Harenberg

No. 228 Roberto C. Panzica

No. 227 Mila Getmansky, Ravi Jagannathan, Loriana Pelizzon, Ernst Schaumburg, Darya Yuferova

No. 226 Loriana Pelizzon, Marti G. Subrahmanyam, Davide Tomio, Jun Uno

No. 225 Monica Billio, Massimiliano Caporin, Lorenzo Frattarolo, Loriana Pelizzon
Statistical Inferences for Price Staleness

The Pitfalls of Central Clearing in the Presence of Systematic Risk

A Tale of One Exchange and Two Order Books: Effects of Fragmentation in the Absence of Competition

Can Households See into the Future?

Survey Evidence from the Netherlands

Debt Holder Monitoring and Implicit Guarantees: Did the BRRD Improve Market Discipline?

Liquidity Provider Incentives in Fragmented Securities Markets

Lighting up the Dark: Liquidity in the German Corporate Bond Market

Asset Pricing in OLG Economies With Borrowing Constraints and Idiosyncratic Income Risk

Idiosyncratic Volatility Puzzle: The Role of Assets' Interconnections

Stock Price Crashes: Role of Slow-Moving Capital

Central Bank-Driven Mispricing?

Networks in risk spillovers:

A multivariate GARCH perspective 